\title{
LEASING IN THE WESTERN BALKANS AND THE FALL OF THE AUSTRIAN HYPO-ALPE-ADRIA BANK
}

\author{
Chris Bryant: "The [Hypo-Alpe-Adria Bank] group incurred \\ a net loss of Euro 1.58 billion [in 2009], thanks to problematic \\ leasing and cross-border financing portfolios [...]."1 \\ [Emphasis added.]
}

\begin{abstract}
The hybrid contract known in Continental Europe as leasing has arrived to the Balkans and other post-socialist countries of Europe from the United States yet with the intermediation of various Western European jurisdictions that have reshaped the contours of the newcomer transaction to fit the context. Western European banks expanding to the region then brought with them their home country perceptions. This resulted in significantly differing leasing laws in the region. Although the process began already before the 1980s, one could speak of real expansion only from the 1990s on. By now leasing has become an important part of most jurisdictions of the region.

Notwithstanding the organic growth, the article posits, leasing is still not properly understood, the regulations suffer from gaps and are inappropriate to boost the local leasing industries. This is readily proved by most recent reports of some international organizations. Especially small and mid-scale enterprises suffer as equipment leasing remains underdeveloped, what is a major systemic defect as bank credit is (as well) unavailable to them.

The article aims to identify and comment those common deficiencies of the leasing laws of this niche of Europe that have so far been neglected yet the tackling of which is
\end{abstract}

* Professor of law, Department of Legal Studies, Central European University (CEU), Budapest, Hungary. Contact email: tajtit@ceu.edu. For a select number of downloadable publications of the author see his SSRN Author page at http://ssrn.com/ author=328809 or at Researchgate https://www.researchgate.net/profile/Tibor_Tajti. The author expresses hereby his gratitude for the exchanges related to this article to Professor Harald Eberhard (WU - Vienna University of Economics and Business) and help with research to Patricia Živković and Albana Karapanco.

1 Bryant, C., Finance Probes Stretch Limits of Justice System, WSJ, 22 Oct. 2010 issue, at 3 (special supplement on Austria). 
inevitable to boost the local industries. This is done, first, by sketching the experiences with and the judicial responses to a few unreported first generation leasing cases from Vojvodina (Serbia) from the end of the 1980s to determine what main problems the lessor faced in implementing their leasing transactions. It is claimed that some of the key problems have not been eliminated from the legal system ever since, in particular the problems with repossession upon default. Secondly, comparative law is as well resorted to yet contrary to European approaches with more insight into the solutions of the United States as the jurisdiction wherefrom leasing originates.

The final part then comments those key problems and dilemmas that still hinder the proper development of the local leasing industries yet which have been largely bypassed. These are the 1/ problems caused by uncritically taken over solutions and definitions, 2/ the lack of legal tools for prompt repossession of the object of leasing, 3/ the conceptual confusion related to what in common law is known as the 'election of remedies doctrine', as well as 4/ the incomprehension of the importance of the policy choices justifying the recognition and judicial support for the so-called hellor-high-water clauses.

The article additionally posits that the very same reasons might have generated the problematic leasing portfolios of the Austrian Hypo-Alpe-Adria Bank and therefore might have also contributed to the eventual fall of the Bank. In the lack of empirical evidences and other firm evidences, however, this position should not be taken to be more than a question to be answered in the future, if for nothing else, then for having some satisfactory answers for the fall of the Bank and for the sake of better understanding leasing.

Key words: leasing (operating, financial), equipment leasing, bank bailout, selfhelp repossession, legal engineering, small and mid-scale enterprise (SME) financing, law reforms.

\title{
List of Abbreviations And ACRONyms
}

\author{
$\mathrm{BiH}$ - Bosnia and Herzegovina \\ CEE - Central and Eastern Europe \\ DCFR - Draft Common Frame of Reference (Europe) \\ EBRD - European Bank for Reconstruction and Deve- \\ lopment (London, UK) \\ ELFA - Equipment Leasing and Finance Association (US) \\ EU - European Union \\ GSA - Federal Act on the Constitution of a Wind down En- \\ tity (Austria) \\ HETA - HETA Asset Resolution AG \\ Hypo Bank, the Bank - The Hypo Alpe-Adria Bank (Austria)
}


ROT - Retained title (ownership)

SME - Small and mid-scale enterprises

UK - United Kingdom

US - United States

\section{INTRODUCTION}

\subsection{WHAT SHOULD BE UNDERSTOOD UNDER 'LEASING' IN CENTRAL AND EASTERN EUROPE}

While the term 'leasing' should not be foreign to lawyers and businessmen in much of Central and Eastern Europe (CEE) ${ }^{2}$ these days, the perceptions are far from being unanimous. ${ }^{3}$ It is fair also to claim that number of those concomitant legal issues that remain obscure is still more than handful. For these reasons, it is important to set out by clarifying what should be understood more exactly under 'leasing' not only on the Balkans but in the neighbouring civil law jurisdictions as well.

First, leasing is often referred to as a title-finance or acquisition finance instrument. What is less known is that besides leasing - and its sub-variants (e.g., operating, financial or sale and lease-back leasing) conditional sales, hire-purchase and consignments ${ }^{4}$ belong here as well and these are the globally most widely used devices of the sort. Contrary to some opinions, 'rent a car' 5 arrangements do not qualify: these are rather specific forms of 'true-leases' because the intention of the parties is never to acquire title (ownership) on the object of the transaction. Admittedly, however, often exactly the distinguishing of 'true leases' and 'leasing' transactions is that creates headaches to lawmakers, regulators or courts

2 For the purposes of this paper the phrase 'post-socialist CEE' countries of jurisdictions encompasses only the former socialist states of Central and Eastern Europe from the former Yugoslavia, Hungary, Slovakia, the Czech Republic and Poland in the West, and the successor countries of the Soviet Union in the East. CEE without the epithet of 'post-socialist' already includes Austria and Germany.

3 For a comparison of the leasing laws of Lithuania, Hungary and Poland see Tajti, T., Security Rights and Insolvency Law in the Central and Eastern European Systems, in: McCormack, G., Bork, R. (eds.), 2017, Security Rights and the European Insolvency Regulation, Cambridge-Antwerp-Portland, Intersentia, pp. 571-692.

4 For a comparative overview of consignment law in the US and Europe see Tajti, T., Consignments and the Draft Common Frame of Reference, Pravni zapisi, vol. II, no. 2 (2011), pp. 358-397.

5 Admittedly a position taken in the early days of leasing's presence on the Balkans enlisting rent-a-car under the category of 'leasing' ("posao lizinga"), for example, is in the textbook Vilus, J., Carić, S., Šogorov, S., 1984, Međunarodno privredno pravo, Beograd, Naučna knjiga, p. 232. 
expected to decide related cases. ${ }^{6}$ The unclear borderline between the two remains a dilemma in CEE as well to this day.

These transactions may legitimately be put under the heading of title-finance because each of these relies on retained title (ownership) as the main security for the lessor, conditional seller, hirer or consignor respectively. It was not without a reason that Leaseurope emphasized that "one feature of all lease contracts that remained unchanged since leasing was first introduced in Europe in the early 1960s [is that] the lessor remains the legal owner throughout the term of the contract."

They are also acquisition finance ${ }^{8}$ transactions because their main economic utility is exactly acquisition of various assets from motor vehicles to equipment. Although these two overlap, they are not identical types of financing though the difference between them is not only on what feature of the transaction is the emphasis put on. The best example to prove this point is the transaction known in common law legal systems as chattel mortgage; often translated to or known as 'registered pledge' or 'registered charge' in civilian systems. Namely, while this transaction qualifies as an acquisition device it is a transaction that does not rely on retained title. Rather, similarly to real property mortgages (mortgage of immovables), the creditor is secured by the security right (lien) registered for his benefit on an asset that, however, is not real property (mmovable) but rather a movable, a right or a claim. Moreover, while title finance contracts are supplier instruments, acquisition finance includes also banking finance in case of which the bank gives a loan to the borrower to purchase a specific asset upon which then a security interest (charge, registered pledge) is created.

The greatest advantage - what made 'leasing' extremely popular also in CEE - is that based on each of these devices the acquirer immediately gets possession of the object of the transaction and it can use it without delay to generate income from which to pay (also) the instalments to the lessor, conditional seller, hirer or consignor. This is economically an enor-

6 See for US law in particular UCC section 1-203(a) that reads "Whether a transaction in the form of a lease creates a lease or security interest is determined by the facts of each case."

7 Leaseurope and Andersen, A., 1992, Leasing in Europe, London, McGraw-Hill Book Co., Statement on Lease Accounting, p. x.

8 Besides leasing and other transactions based on retained title (ownership), acquisition finance includes also chattel mortgage and kin transactions when a lender extends a loan to the debtor for acquisition of specific tangible asset, which then serves as collateral and security. In many jurisdictions in CEE such transactions, figuring under different designations, have become subject to registration in a public register. In Serbia, these are the Register of Charges ("registar zaloge"). On the meaning of acquisition finance, see, for example, UNCITRAL Legislative Guide on Secured Transactions, 2010, New York, paras 6-12, pp. 320-21. 
mous advantage over possessory pledge that does not allow for transfer of possession on the object to be acquired on credit immediately upon conclusion of the underlying contract but only after the credit has been repaid.

This difference is crucial because all socialist legal systems had suffered from this malady at the time of the fall of the Berlin Wall: only possessory pledges were available as in rem (possessory) security devices if movables (goods, rights and claims) were at stake. Real property mortgages were known yet they did not really function in practice as evictions were not compatible with the policies of socialism ${ }^{9}$ and consequently no deep markets could have developed; simply in case of default the mortgage on residential property could not be enforced, or only with substantial delay and red tape. Foreclosure (enforcement) of mortgage on immovables owned by the state, or in societal-ownership ("društvena svojina") in the former Yugoslavia, was even more problematic because the enterprises that owned these were the protégés of the former regimes.

Second, it should be borne in mind as well that the typology of title or acquisition finance contracts differed in the common law systems that originated them, too. While hire-purchase is unknown in the US and is presumably the most frequently used device in the United Kingdom (UK), conditional sales and leasing are known in each of these countries and are the most frequently used devices in the US. ${ }^{10}$ Idiosyncratic sub-variants are also known, like the bailment-lease in some States led by Pennsylvania as the 'leading bailment-lease state."

9 As Harmathy eloquently put it related to the mentality inherited from socialist in Hungary, something that applied mutatis mutandis to other socialist countries as well, "[f]or many years banks were presented as institutions of capitalists exploiting poor people. Public opinion has been in favour of the poor and against the rich getting dividends and interest, smoking cigars and not working. The mentality of many people has not changed fundamentally during the [years to come]." Harmathy, the EBRD Model Law and the Hungarian Law, in: Norton \& Andenas, 1998, Emerging Financial Markets and Secured Transactions, London, UK, Kluwer, pp. 197-209, 205.

10 As a treatise from 1965 reveals "except Canada and New Zealand the form of agreement generally used is a hire-purchase agreement, and the parties are respectively referred to as the owner and the hirer. In Canada, New Zealand and the United States the agreement used is a conditional sale agreement and the parties are seller and buyer." Given that both Canada and New Zealand have in the mean time reformed is personal property security law following US secured transactions law enshrined into Article (i.e., chapter according to European standards) 9 of the Uniform Commercial Code (UCC) according to which the designation is not determinative anymore and the contracts may be simply called as 'security agreement,' the patterns may have changed. See Goode, R. M., Ziegel, S. J., 1965, Hire-Purchase and Conditional Sale - A Comparative Survey of Commonwealth and American Law, UK, London, British Institute of Int'l and Comparative Law, p. 6.

11 Gilmore, G., 1965, Security Interests in Personal Property, Boston-Toronto, Little, Brown and Co., $\$$ 3.6., p. 77. [Hereinafter: Gilmore, G., 1965.] 
Third, 'leasing' arrived to the Balkans and to CEE with the intermediation of Western European banks and other financial organizations, suppliers of equipment and the knowledge about it partially also through academic channels. It got here as a variable business pattern rather than a precisely formulated model law ready for easy transplantation. This was due to the fact that substantial differences existed not only in the dominating leasing patterns but also in the accompanying laws already in the Western European source-countries. Western European legal scholarship then interpreted leasing law relying solely on their own domestic conceptions and circumstances and disregarding those of others that otherwise might have occasionally been more suitable to some of the CEE countries. The significant differences that have survived up until today in the region's countries to a large extent could be attributed exactly to this, or more precisely which Western European model was looked at by the recipient countries. As it is well-known, the post-socialist systems normally took typically French, ${ }^{12}$ German ${ }^{13}$ or some other developed Western European law as the dominating model.

In that vein, although it cannot be corroborated by empirical evidences, it may be presumed that the Hypo-Bank brought with it the Austrian understanding of 'leasing' that might but must not have fitted the socio-economic and legal environment of the Western Balkans in all respects. As leasing has not become regulated in some jurisdictions up until today, or has been subjected to regulation only partially, the vacuum coupled with leasing laws often influenced by differing sources and in time varying local interpretations resulted in a quite varying landscape of leasing law in CEE. While Serbia or Hungary regulates specifically only financial leasing, in Croatia both operating and financial leasing are covered by the same lex specialis; for instance.

Fourth, although the originator common law countries know more types of title finance devices, interestingly only the one denominated as 'leasing' arrived first to Western European civil law jurisdictions and from there roughly from the 1980s on to CEE. Sometimes the English term was made part of the local language nomenclature, at other times local language equivalents were coined. Though the variability of leasing is due

12 For a detailed overview of the security laws - including leasing - see Carballo Fidalgo, M., Carballo Piñeiro, L., Mangano, R., Security Rights and Insolvency Law in the Roman Legal Systems, in: McCormack, G., Bork, R. (eds.), 2017, Security Rights and the European Insolvency Regulation, Cambridge, Intersentia, pp. 415-571.

13 For a recent overview of Austrian and German security and bankruptcy laws see Bork, R., Security Rights and Insolvency Law in the Germanic Legal Systems, in: McCormack, G., Bork, R. (eds.), 2017, Security Rights and the European Insolvency Regulation, Cambridge-Antwerp-Portland, Intersentia, pp. 173-312. 
also to the fact that the newcomer contract was - based on the venerable principle of freedom of contract - regularly modified according to the desires of the parties. Consequently, depending on what is provided for in the provisions of the contract, how the rights and obligations of the parties are formulated, sometimes such 'leasing' contracts actually are closer to a common law conditional sales or hire-purchase contract rather than what is normally perceived as 'leasing' in common law jurisdictions. The Balkan and CEE 'leasing' is thus a kind of universal substitute for many title finance devices known to common laws. For this reason, for the purposes of this paper the term 'leasing' is appropriate as a shorthand reference to all sub-variants of title finance instruments that may be referred to hereinafter.

To make things more complicated, civil laws tend to know also a sub-variant of sales contracts - i.e., sales with retained title (ownership) ${ }^{14}$ - which may but must not be taken as the equivalent of common law conditional sales contracts. ${ }^{15}$ As it will be argued in this paper below, to the extent the conditional seller's right to repossess (especially out-of-court) is the key, or at least a crucial, element of conditional sales contracts, the two cannot be equated.

Fifth, there is yet another factor that exacerbates the comparative analysis of 'leasing:' the trend of subjecting title finance contracts - including leasing - to secured transactions law. For this reason, especially English legal scholars speak of these as quasi-security devices. ${ }^{16}$ Namely, the central feature of the so-called 'Unitary Model of security interests' introduced by Article (i.e., chapter) 9 of the American Uniform Commercial Code (UCC) is that all transactions where personal property (movables, rights and intangibles) is used as collateral to secure an obligation (credit) should be subject to the same set of rules notwithstanding the naming and

14 See, for example, sections 540-541 of the Serbian Act on Obligations, regulating 'sales subject to retained ownership' ("prodaja sa zadržavanjem prava svojine”).

15 For a discussion on the 'remote equivalents' of conditional sales in Russia see Guseva, Y., Kononov, O., Contract Enforcement in Russia: Positive Developments and Persistent Dilemmas, in: Messmann, S., Tajti, T., 2009, The Case Law of Central and Easter Europe - Enforcement of Contracts, Bochum, Germany, European University Press, vol. II, pp. 806-811. [Hereinafter: Messmann, S., Tajti, T., 2009].

16 As McCormack put it, "English law recognises the possibility of having the functional equivalent of a security interest over property through the use of other legal techniques," which are often referred to as quasi-securities. According to English law they include: " $1 /$ sale and leaseback/hire purchase; $2 /$ title retention/conditional sale; 3/ agency sales financing; 4/ factoring/assignment of receivables; 56/ quistclose trusts; [and] 6/ trust receipts." McCormack, G., Security Rights and Insolvency Law in the Common Law System, in: McCormack, G., Bork, R. (eds.), 2017, Security Rights and the European Insolvency Regulation, Cambridge, Intersentia, pp. 313-415. 
the inherent differences that relate to the non-security aspects of these contracts. This is otherwise based on the so-called 'functional approach' of the UCC and all jurisdictions that have adopted the Unitary Model which is to be distinguished from a systemic approach ${ }^{17}$ characteristic to Continental European legal systems. As it is known, the primary aim of that latter is to forge sophisticated definitions and to place each and every type of contract or legal institution neatly in the system of law. First the Canadian provinces (from the end of 1960s on), then New Zealand (1999), Australia (2009), ${ }^{18}$ and finally the post-socialist CEE countries followed the suit starting from the 1990s on. In Europe, Book IX of the DCFR ${ }^{19}$ seems to be the best follower of this trend in addition CEE countries that have been primarily inspired in this domain by Anglo-Saxon laws. This path was to certain extent stepped onto by some Western Balkan countries as well.

For the time being, this wave of converting leases into secured transactions akin to pledge or chattel mortgage transactions has largely bypassed the Balkans and the regulated forms of leasing are treated separately from the newly introduced 'registered pledges.' The third wave of Hungarian ${ }^{20}$ secured transactions reform introduced by the brand new 2013 Civil Code, however, already made financial leasing subject to registration not in a separate register but exactly in the register where the 'registered pledges' are to be entered. Hungarians have, in other words, partially at least, realized that leasing and registered pledges (or registered charges) are in economic terms kin transactions.

Sixth, a few words ought to be cast on two inter-linked common features of the leasing markets of Western Balkans. We should start with the shared deficiency that was already hinted at above: equipment leasing is

17 More on the differences between topical (pragmatic) and systemic approach to law see Tajti, Viehweg's Topics, Article 9 UCC, the "kautelarische Sicherheiten" and the Hungarian Secured Transactions Law Reform, Vindobona J. Int'l Commercial Law and Arbitration, vol. 6, no. 1, pp. 93-131 (2002).

18 For the commentary of the 2009 Personal Property Securities Act of Australia see Duggan \& Brown, 2012, Australian Personal Property Securities Law, Australia, LexisNexis Butterworths.

19 The DCFR was expected to become the first common Civil Code of Europe. Yet there has not been a political will so far to adopt it by the Member States of the European Union (EU). It is primarily a product of scholars from all Member States of the EU. For details see the Oxford Commentary of DCFR: Bar, C. von, Clive, E., (eds.), 2010, Principles, Definitions and Model Rules of European Private Law - Draft Common Frame of Reference (DCFR), Oxford University Press.

20 Hungary is not a Western Balkans country yet its solutions - just as those of other post-socialist jurisdictions - are useful for our discussion and will thus be frequently referred to. To the best of the knowledge of the author of this paper, however, Hungarian law has not significantly and directly influenced the leasing or security laws of the Western Balkan countries. 
underdeveloped and the overwhelming part of the markets is focused on motor vehicle leasing. This structural distortion then makes the life of SMEs, especially start-ups, hard. While admittedly the desirable structural changes hardly could be effectuated without fiscal and other macro-economic supportive measures, law has its share to contribute with as well. Indeed, some of the methods whereby equipment leasing could be boosted yet which are "in law's hands" will be presented herein below.

Another distinguishing feature of theses leasing markets is that they are dominated by banks and what the industry calls 'captives', or affiliates of banks or sometimes of large manufacturing corporations. Independent leasing companies, that play a significant role for example on US markets, ${ }^{21}$ are a-typical for this niche of Europe at this point in time. This inevitably affects then the competition on the market as banks are typically conservative players that do not easily venture to uncharted territories. These points to a great extent apply also to the rest of post-socialist systems in the rest of CEE.

Last but not least, irrespective the variations in the national laws, leasing as a sui generis business pattern and the local leasing industries do share many features in the region's countries as well. While the written laws and even the positions of higher courts may often differ, especially the problems faced by the local leasing industries that hinder their growth are similar if not identical. These commonalities allow us to draw conclusions that apply to most of them though obviously in varying degree. This notwithstanding, the traditional caveat applies here as well: before making concrete business decisions, local counsel should always be consulted.

\subsection{THE HYPOTHESES}

This article has three inter-linked hypotheses. The first hypothesis - which we may conveniently refer to as 'the cognitive and regulatory gap hypothesis' - is that notwithstanding the major advancements made in the region in regulating leasing and spreading this business model, dilemmas and open issues remain. Leasing, in other words, is still not fully understood and consequently the pertaining regulatory framework is as well in need of improvements. The central problem seems to be that the

21 According to the 2017 Survey of Equipment Financing Activity of the US Equipment Leasing and Finance Association (ELFA), besides banks and captives, independents occupy about $7 \%$ of the total US equipment leasing market. Id., page 6, (https://www. leasefoundation.org/wp-content/uploads/2017/07/2017sefaexecutivesummary.pdf, 24 January 2018). In the US, while the expansion of banks is often hindered by red tape (extensive regulations), captives are focused on satisfying the financing needs of their parent manufacturing companies. Id. 
emphasis of leasing laws is misplaced and is not focused on those points that could boost the local leasing industries. Instead of paying adequate attention to the legitimate requests of the industries, systemic considerations characteristic to civil laws prevail.

The second hypothesis, 'the economic growth hypothesis', propounds that the imperfections inevitably hinder not only the further organic growth of local leasing industries but also make (especially) acquisition of modern equipment by the low-capitalization local businesses next to impossible. ${ }^{22}$ Those questioning this claim are advised to take a look at the 2016 finding of the European Investment Bank (EIB) ${ }^{23}$ that reports about shrinking leasing sectors, large portfolios of problematic leases, dominance of vehicle leasing, underdeveloped branch systems and lack of familiarity with leasing products. ${ }^{24}$ These deficiencies and underdeveloped equipment leasing sectors hit especially SMEs that cannot offer quality collateral to get bank loans. These are the reasons why, for example, EBRD provides loans specifically to promote equipment leasing for the small and mid-scale enterprise sector in some countries of Western Balkans. ${ }^{25}$

The third hypothesis, which will be named as 'the empirical hypothesis' herein, posits that the misunderstanding of the phenomenon of 'leasing' and the legal environment of the countries of the Hypo-Alpe-Adria Bank's operation have presumably been a major contributing factor behind the fall of once Austria's fifth largest bank. As critical analyses of the Bank's fall are lacking to a great extent due to the fact that the fiasco

22 See, e.g., the Report of the Serbian National Bank on the Sector of Financial Leasing for the third quarter of 2017, point 3.1., page 12 according to which the market is clearly dominated by leasing of all sorts of motor vehicles. See Narodna Banka Srbije, Sektor Finansijskog Lizinga u Srbiji - Izveštaj za treće tromesečje 2017. godine, (http:// www.nbs.rs/internet/latinica/57/57_3/izvestaji/FL_III_2017.pdf, 13 January 20189.

23 EIB, Assessment of Financing Needs of SMEs in the Western Balkan Countries - Synthesis Report (August 2016), (http://vienna-initiative.com/wp-content/uploads/2016/09/ EIB_assessment_of_financing_needs_of_smes_in_the_western_balkans_synthesis_ en_compressed.pdf, 22 January 2018).

24 Id, page 20-21.

25 See, e.g., Rosca, O., $€ 60$ million in new EBRD financing to Serbia's Banca Intensa and its leasing unit (14 November 2017), (http://www.ebrd.com/cs/Satellite?c=Content\&cid=1395266876999\&d=Mobile\&pagename=EBRD\%2FContent\%2FContentLayout, 20 January 2018) and Reiserer, A., € 20 Million to UniCredit Leasing Croatia, (http://www.ebrd.com/news/2017/ebrd-provides-20-million-loan-to-unicredit-leasing-croatia.html, 20 Jan. 2018). While one of the loans to the Serbian leasing company aims "to provide long-term funding to Serbian SMEs seeking to lease commercial vehicles, equipment and property," the Croatian one is given "for the expansion of leasing finance especially to micro, small and medium-sized enterprizes [to] strengthen the growth of Croatia's economy." 
remains a politically sensitive issue and empirical evidences are non-accessible publicly, a thorough analysis of this specific contributing factor has hereinbefore been neglected. This article admittedly is, neither in the position, nor is aimed at filling this vacuum. However, it will try to come forward with some plausible explanations.

It is also hoped that the analysis to follow related to all hypotheses will be instructive not only for the region's countries striving to improve their leasing-related regulatory frameworks ${ }^{26}$ but also for other emerging systems like China ${ }^{27}$ that are more recently faced with the challenges surrounding the regulation of leasing.

\subsection{THE ROADMAP TO THE PAPER}

In order to prove the hypotheses, the article will, first, fill the gap in comparative scholarship by sketching the history of leasing in the decades preceding and following the fall of the Berlin Wall up until present time in the post-socialist countries of Central and Eastern Europe (CEE) though with focus on the Western Balkans. This requires canvassing the main milestones of the evolutionary process as well as the key commonalities and differences of select leasing laws and leasing industries of the region.

Secondly, besides sketching the expansion, fall and the subsequent developments of the Hypo Bank saga - in particular trying to highlight the key data on its leasing-related activities - the paper uniquely offers insight into an unreported leasing case study from the northern Province of Serbia (Vojvodina) from the end of the 1980s and the beginning of the 1990s. These are resorted to not only to demonstrate that entrepreneurship and interest in western tested business patters was present in this niche of Europe once the winds of change reached the Balkans but also to identify what problems might have awaited the Hypo Bank upon its arrival to the Western Balkans at the beginning of the 1990s. As empirical evidences on the concrete business practices and the concrete problems faced by the Hypo Bank are lacking, the local leasing cases do reveal what the key hurdles the local lessors faced in trying to enforce their leases were. As it will be seen, many of the initial problems survived up until today notwithstanding the subsequent regulatory interventions.

26 Ukraine may be a good example because a new draft Law on Financial leasing was submitted to the Ukrainian Parliament in 2017. This act is to replace the first that was enacted on $14^{\text {th }}$ of January 1999.

27 See, e.g., Williams M., Lu H. and Ong, C. A., Secured Finance Law in China and Hong Kong, Cambridge, 2010, page 262 et seq. 
The ultimate goal is, last but not least, to identify those features and sine qua non elements of leasing law that might have not only contributed to the fall of Hypo-Alpe-Adria Bank but which (or at least some of which) are still surrounded by incomprehension in this niche of Europe. These are at the same time those topics the proper understanding and adequate regulation of which could boost the local leasing industries as well, in particular equipment leasing. Given the focus on problems and solutions rather than on formal (written) law, it should be clear to the reader that this paper does not propagate mechanic but rather fit-to-context transplantation, moreover, not based on any single jurisdiction's law but rather based on understanding the phenomenon of leasing through perusal of the experiences of multiple legal systems.

\section{Two EXPERIMENTS With LEASING ON THE BALKans JuXTAPOSED}

\subsection{LOCAL LEGAL ENGINEERING: THE UNREPORTED LATHE-LEASING CASE STUDY FROM VOJVODINA ${ }^{28}$}

\subsubsection{The Legal, Economic and Political Environment in the Late 1980s and early 1990s Serbia in a Nutshell}

As this paper is focused on the Western Balkans and on the successor countries of the former Yugoslavia, canvassing of the key features of these legal systems as well as the peculiar socio-economic and political circumstances in which leasing set foot in this niche of Europe is a must.

One has to start with the history pages in order to set out the narrative. The first thing to be noted is that the end of the 1980s in the former Yugoslavia was characterized by attempts to start the transition towards multi party democracy and transformation of the planned into a market economy. This process was then stopped with the outbreak of the war on the Balkans, which affected the various parts of the former Yugoslavia with varying intensity depending on the proximity of the war zones. As the war impacted various parts of the former Yugoslavia differently, economic development and reforms of the legal system left these countries at differing stages as well. Admittedly, accession to the EU gave an enormous push to Slovenia and Croatia in all respects; the only post-Yugoslav countries that acceded the EU in 2004 and 2013 respectively so far.

28 Vojvodina is the northern province of the Republic of Serbia, both of which were part of the former Yugoslavia. Vojvodina had no private or commercial law of its own during the time period in the purview of this paper. 
Notwithstanding the differences, however, the post-Yugoslav jurisdictions share many traits of relevance to our discussion on leasing. In particular all the successor states inherited the laws of the former Yugoslavia, most of which were later either amended, or repealed and replaced by new laws. This includes the Act on Obligations ${ }^{29}$ that together with a number of specific statutes governed the core areas of private and commercial law. Leasing as such was not regulated in Yugoslavia: that was the product only of the $21^{\text {st }}$ century that brought with it major headways with domestication of leasing. By early 2018, when this article is finalized, however, leasing has become part of the business practices basically of all the successor countries and of the laws of these legal systems. This primarily should be attributed to the appearance in the region of western banks and financial organizations that employed their business patterns as well; including leasing. In this respect the Hypo Alpe-Adria Bank had played not only a pioneering but the leading role in the region until its collapse.

It is also part of the story that the leasing cases referred to below were introduced during the last years of the 1980s, which was the era of the first generation of reforms, when it was already felt that things will change, both in politics and in economy. The country, earlier in constant economic crisis, burdened by budgetary deficits, shortage of foreign currency and fast-changing regulatory environment suddenly felt an unexpected dose of stability especially due to the short-lasting reforms ${ }^{30}$ of prime minister Marković roughly between 1989 and 1990, when inflation was sharply decreased through pegging the national currency (Dinar) to the German Mark at the 1:7 level. ${ }^{31}$ Permission was also given to citizens to buy foreign currency in banks. Many of administrative regulations suffocating business and suppressing entrepreneurship

29 Zakon o obligacionim odnosima 1978. Hereinafter: Act on Obligations. Yugoslavia did not have a civil or commercial code, or in other words it was not a monist state. Instead, more pieces of legislation covered these fields.

30 This included sudden passage of a series of major systemic laws, starting with a new Enterprize Act ("Zakon o preduzećima 1989") that represented a crucial yet perhaps too shy step ahead. As Allcock put it, "the question of property reform was defined as off limits until it was too late." Allcock, J. B., 2000, Explaning Yugoslavia, London, Hurst \& Co., p. 96. For a synopsis of the key laws and the overview of the rules on directors' liability as per this act see Beširević, V., 1989, Odgovornost za privredne prestupe i prekršaje prema odredbama Zakona o preduzećima, Savremena praksa, vol. 24 , no. 1296 , pp. 1-2.

31 See, e.g., section 7.11 in Jović, D., 2009, Yugoslavia - A State that Withered Away, Indiana, Purdue University Press, pp. 353-374. [Hereinafter: Jović, D., 2009]. See also Benson, L., Yugoslavia - A Concise History, 2001, Palgrave, p. 158 et seq. [Hereinafter: Benson, L., 2001]. It ought to be stressed that both books deal primarily with the political rather than the economic aspects of the history of the former Yugoslavia. 
were repealed as well. For example, it became suddenly lawful to express moneys to be paid as per contracts made by domestic parties in German Marks yet to effectuate the payment in local currency at the time of performance; a practice that was widely resorted to before the policy shift in the informal market given the years-lasting volatility of the local currency and high inflation.

The winds of change, a kind of reform atmosphere, were felt also in court rooms and formalism was supplanted by modest but encouraging dose of judicial activism and flexibility, among others, when faced with such new business contracts as variations of leasing - something visible even from the pages of the few cases discussed below. Although relatively short-lived yet the reform atmosphere was undoubtedly due that the local leasing cases to be elaborated upon in more detail below came into being and that the officers of the company from Vojvodina dared to experiment with leasing at all.

Markovićs reforms, advised by the American economist Jeffrey Sachs, however, inflicted as well great hardships throughout the country as the reform measures were radical and in many respects exceeding the capabilities of the economy and the tolerance level of the citizenry. ${ }^{32}$ These have also contributed to the eventual fall not only of Marković but of all the reform-oriented forces in the society giving way to a shift towards nationalism and the outbreak of the wars on the Balkans. The war, as already hinted at, have postponed transition and the introduction of the cogwheels of democracy and market economy for years as compared to the rest of the Eastern Bloc.

\subsubsection{The Impact of the Balkan Wars and the United Nation's Embargo on the Leasing Cases}

The Balkan wars impacted all contracts, including the many leasing contracts concluded by the company from Vojvodina. Quite suddenly, namely, most of the lessees defaulted with their leasing contracts; some intentionally. Often all channels of communication stopped with the lessees, especially though not exclusively in case of partners seated in places close to the combat zones outside of Serbia.

Three scenarios could have been differentiated thereafter. Some partners, both from within and outside Serbia, were willing to settle out-ofcourt amicably. Normally, they offered either their products, or those of others, instead of payment in cash.

32 See Benson L., 2001, p. 158. 
More frequently, however, all the concerns that surround litigation in a hostile jurisdiction surfaced if the partners were not from Serbia or Montenegro (i.e., rump Yugoslavia). Thus, if court proceedings have already been started, one could have proceeded as if nothing had happened in the hope that eventually things will be settled in courtrooms. Yet often the wisest option was simply to write down the claim and not to waste any moneys on the litigation-related costs and expenditures.

As per the third scenario, the lessees were from Serbia and thus the court system in principle should have been in the position not only to summon the parties or witnesses to the courtroom, but also to take all the other procedural acts necessary for proper conducting of the proceedings, including enforcement of final judgments. Yet as it might be presumed, especially during the first few years of the 1990s roughly until after the Dayton Agreement (14 ${ }^{\text {th }}$ Dec. 1995), the system could not function as one would have expected. Often courts simply could not deliver their writs or summons even at the price of more attempts, or use of the assistance of the postal services or of the police, let alone enforce judgments ordering return (repossession) of the object of leasing.

The sanctions of the United Nations in 1992 and the concomitant embargo further exacerbated the situation because within a quite short period of time all companies that had substantial income from abroad became technically bankrupt. ${ }^{33}$ This meant that albeit on their books they had significant claims to be paid by foreign partners, due to the sanctions the foreign partners were prohibited from transferring them. In a few months the ripple effect of the frozen assets was that these export-dependent firms could not pay their domestic partners either, a spiral that reached the subsequent generations of claim-holders as well though with some delay in time. This could not but negatively affect eventually the financial capabilities of lessees from Serbia many of whom were as a result forced to default with payment of instalments. Some, however, withheld their payments intentionally awaiting the lifting of the sanctions and resumption of doing business as usual.

33 Differing definitions of technical bankruptcy (or insolvency) exist. For example, Investopedia defines 'technical bankruptcy' as "A situation in which a firm is unable to meet its current obligations as they come due, even though the value of its assets may exceed its liabilities." See Investopedia, Bankruptcy Risk, (https://www.investopedia.com/terms/b/bankruptcyrisk.asp, 20 January 2018). Some authors limit the definition to liquidity. For example, as Altman and Hotchkiss put it "Technical insolvency exists when a firm cannot meet its current obligations, signifying a lack of liquidity." Altman, E. I., Hotchkiss, E., 2006, Corporate Financial Distress and Bankruptcy: Predicts and Avoid Bankruptcy, Analyze and Invest in Distressed Debt, $3^{\text {rd }}$ ed., Wiley \& Sons, p. 62. 


\subsubsection{The Phases of the Expansion of Leasing to the Balkans and to CEE}

Hard evidences are lacking yet there seems to be a common understanding that the hybrid transaction 'leasing' ${ }^{34}$ had arrived to the Balkans and to other socialist states first through equipment acquisition-targeting cross-border transactions concluded with western partners. The beginning of this process goes back to those decades of the $20^{\text {th }}$ century when these countries were legitimately referred to by some western scholars as 'nonmarket economies' characterized by "strict central planning of all production [...] [including subjection of trade and investment] to restrictive rules." ${ }^{35}$ In this inaugural phase, leasing was one of those suitable transactions that had by then already gained a solid foothold in the western jurisdictions the companies of which were exporting equipment to Yugoslavia. One may suspect thought that the employment of leasing was normally required by the westerners. For this reason, it is justified to name this inaugural stage as 'the era of import-linked leasing transactions.'

Given that leasing has arrived to Western Europe initially from the United States (US) and that the integration and spreading of this peculiar transaction in Western Europe occurred as well in the second half of the $20^{\text {th }}$ century, one may suspect that the number of encounters of eastern businessmen with leasing has also increased over time parallel with this process in Western Europe. Consequently, while in the 1950s and 1960s leasing "has not been common in East-West commercial relations," 36 that seems to have changed by the 1980s though obviously with differing intensity in the various parts of the Eastern Block. As the socialist enterprises of the former Yugoslavia enjoyed much more freedom in structuring their business relations with western partners than the enterprises in the $\mathrm{COMECON}^{37}$ countries, the salesmen and officers of these were more often in the position to directly encounter such novel business models as

34 The naming and spelling patterns differ. For example, while the Serbian Law on Leasing in its Serb language variant speaks of 'lizing,' the Croatian one rather kept the English spelling and uses 'leasing.'

35 Folsom, R. H., Wallace. G. M., Spanogle, Jr., J. A., 2003, International Business Transactions, $6^{\text {th }}$ ed., Thomson-West, p. 15.

36 See Burack, L. M., 1969, American Private Direct Investment in Eastern Europe: Intersection of Business Interests and Foreign Policy, 21 Stanford Law Review 877 (April), note 57 citing Eckstrom, Foreign Licensing - Business Considerations and Problems, in: 1 Proceedings of the 1959 Institute on Private Investments Abroad 525, at 545-54 (1959).

37 COMECON stands for Council for Mutual Economic Assistance (in Serbo-Croat: "Savet za uzajamnu ekonomsku pomoć"). This organization existed between 1949 and 1991. While Yugoslavia was only an associate member, its socialist neighbours 
leasing. Although export-import was centralized in the other European socialist states well into the 1980s, the westernmost countries of the Bloc were much more exposed to western influences than the others. Still, as the main feature of this era was lack of any regulation of leasing, it makes sense to refer to it as the 'phase of regulatory vacuum.'

Taking the example of Yugoslavia, the liberalization coupled with the lack of any law or regulation of leasing was an impetus for some legal engineering and for the very first time for exploiting new business models. The leasing cases to be analysed below were product of these years and of such an environment.

The true domestication of leasing, however, ensued only starting somewhere in the first half of the 1990s, when the first foreign banks began their expansion to the Balkans. The Bank that was among the first and that seems to have been most successful in spreading in the West Balkan countries was, indeed, the Hypo Alpe Adria Bank.

The post-war period, denoting different points in time for the countries of the region, was a non-linear, alternating-speed process chequered with unforeseeable stops, decelerations and abrupt headways, contingent on such external factors as the remoteness, intensity and the effects of the Balkan wars or - in case of Croatia and Slovenia - accession to the European Union. From the perspective of 2018, however, one could safely claim that notwithstanding the unprecedented obstacles, leasing has made its way to the economies of all the Balkan countries in this or that form. Leasing is today therefore part of the law of each of these countries though with significantly differing features and economic roles. As the post-war period is primarily characterized by the gradual introduction of leasing regulation, two phases should be distinguished.

In the first inaugural regulatory phase - the phase of first generation leasing laws - the first leasing laws were passed. It is fair to claim that in this phase the new law predominantly belonged to the domain of commercial law. The lawmakers followed the traditional civil law pattern of focusing on the definition of leasing and the rights and obligations of the parties typically influenced by one or more models from Western Europe.

Later, however, the focus switched to regulation of the leasing industry, where the goal was already on ensuring that only properly licensed, staffed, capitalized and governed entities could provide services on the leasing market; naturally subject to oversight by increasingly sophisticated regulatory agencies. Leasing companies in this phase are already treated

(Hungary, Romania and Bulgaria) were full members. Albania is normally depicted as a non-participating member. 
as financial organizations subject to red tape similar to that of banks. This 'financial regulation-dominated phase' is where the leasing systems of most of the post-socialist legal systems of CEE are now at the beginning of year 2018.

Such phase-by-phase development of leasing law could be tracked down in most of the systems not only on the Balkans but also in the other post-socialist systems as these represent phases of natural organic growth. In Serbia, the first lex specialis devoted to leasing - limited only to financial leasing - was passed in 2003, which then was amended more times. It is indicative that it was only the 2005 amendment that exposed leasing companies to heavy oversight by the Serbian National Bank. ${ }^{38}$ Financial leasing transactions have become subject to registration as well. ${ }^{39}$ The fate of leasing was similar in Croatia as well, where leasing survived unregulated until 2006, when the first leasing act was passed, which was repealed and supplemented by a brand new one already in $2013 .{ }^{40}$ The approaches, however, are far from being the same. As already mentioned, for example, as opposed to Serbia where only financial leasing is regulated, the Croatian Law on Leasing covers both operating and financial leasing. ${ }^{41}$

However, it is not only the leasing acts that should be paid attention to because parallel with this leasing-focused process the number of regulations that indirectly apply to leasing have increased as well. ${ }^{42}$ These were all milestones along the road leading to an increasingly more mature industry and regulatory environment. In the end, leasing (especially financial leasing) has metamorphosed from an unregulated commercial transaction, novel type of contract the contours of which were primarily shaped by innovative counsel and courts based on commercial law, to a financial service subject to an increasingly complex set of financial regulations. The stiffening of regulations normally resulted also in the cleansing

38 The Serbian National Bank was entrusted, among others, with issuance of licenses for conducting financial leasing transactions, approval of the structure of leasing companies' governing bodies, oversight of their activities as well as with the right and duty to impose certain measures.

39 Financial leasing transactions are subject to registration with the Business Registers Agency ["Agencija za privredne registre"], (http://www.apr.gov.rs/, 7 January 2018), which maintains a separate register on financing leasing transactions, (http://www.apr. gov.rs/eng/Registers/FinancialLeasing/FinancialLeasingRegister.aspx, 7 January 2018).

40 Zakon o leasingu, Narodne Novine No. 141/2013. Text downloadable in Croatian language at the website of the Croatian Financial Services Supervisory Agency HANFA ("Hrvatska Agencija za Nadzor Financijskih Usluga"), https://narodne-novine.nn.hr/ clanci/sluzbeni/2013_11_141_3011.html, 7 January 2018.

41 See section 5 of the Croatian Act on Leasing of 2013.

42 For the long list of regulations of relevance to leasing [in English language] see the website of HANFA (http://www.hanfa.hr/regulations/leasing/, 7 January 2018). 
of the leasing market and the number of leasing companies operating has decreased rather than increased. ${ }^{43}$

Leasing law therefore today rests on two feet in most of these systems: the regulatory and the commercial law prongs - what is otherwise characteristic of mature legal systems as well. In light of that, it ought to be added here that this article will focus only on the latter. Further, this article will not deal with some quite unusual forms of leasing, or more precisely with legal arrangements that resemble leasing and which may even be occasionally referred to as 'leasing' yet the true legal nature of which is places them far from such paradigm leasing forms as either equipment or motor vehicle leasing that are normally treated also as financial services subject to peculiar financial regulations. ${ }^{44}$

The ultimate score of these processes is that today many of the post-socialist systems have developed leasing regulatory systems, some of which equalling or even surpassing those possessed by some Western European jurisdictions. The key distinguishing factors concern rather the efficiency of the enforcement of leasing-based rights of both parties to the transaction, or the difference between written and living law, as well as the depth of the leasing markets. This notwithstanding, as this paper will try to show, open issues remain the clarification of which undoubtedly could give a further boost to the exploitation of this many-faceted transaction in the region.

\subsubsection{The Lathe-Leasing Cases from the Serbian Province of Vojvodina}

\subsubsection{Why Documenting?}

What is less known and seems to have remained unreported is that experimentation with the introduction of a version of leasing in this niche of Europe had occurred even before the Hypo Bank appeared in this territory; already during the 'phase of regulatory vacuum. Although hardly could one find empirical evidences or scholarly papers from which it

43 In Croatia, for example, while in 2005 there were 66 leasing companies registered with HANFA, that number decreased to 18 by 2016. See the website of HANFA (http://www.hanfa.hr/publications/statistics/\#section3, 7 January 2018).

44 Labor law may serve as an example, where sometimes employees - instead of being employed based on an employment contract - are rather only 'leased' for performance of some specific jobs. See, e.g., Zdravković, M., Iznajmljivanje (lizing) zaposlenih u Srbiji, [Rent (leasing) of employees in Serbia], (https://www.schoenherr.rs/ fileadmin/content-rs/articles/pdf/Roadmap2014_Iznajmljivanje_(lizing)_zaposlenih_u_Srbiji.pdf, 7 January 2018). 
could be seen whether experimentation with leasing had occurred already during those early years yet it should not be doubted that some local firms and banks had, indeed, begun pondering about employment of the then already famous 'leasing' contract already somewhere in the 1980s. This because often leasing was perceived unrealistically as a kind of nothingcan-go-wrong device and as the unquestionable token of business success.

In this paper, the primary source of data and information about those years are based on a handful of leasing cases introduced by a lathe-manufacturing company once named as 'Potisje' seated in the northern province of Serbia, Vojvodina. As the author of this paper had insight into the underlying contracts and most of the court files of these cases, as well as had seen the practical difficulties with enforcing the lessor's (i.e., Potisje's) rights, in the period between the end of the 1980s and the first years of the 1990s, these can be exploited to sketch the main features of the leasing cases and draw some lessons on the first encounter of leasing contracts with local courts and local businessmen appearing in the shoes of lessees.

Given the personal involvement, the traditional caveats apply. In particular, the focus will be on those elements and factors that may reasonably and objectively ascertained or assessed by the reader as well. This will be achieved primarily by limiting the discussion only to key provisions in the underlying leasing contracts as well as quoting and commenting on the most interesting parts of the court decisions made in some of these cases. The repossession-related (i.e., return of the object of leasing) parts, however, rest solely on the observations of the author as no court files are available on the enforcement phase. This because, as it will be discussed below, court enforcement did not function properly in those days and normally court enforcement proceedings were not even requested by the lessor.

As already stressed, the main goal of this exercise is to identify those issues and problems existing in the initial phases of leasing's entry to the Balkans that might have contributed to the problematic leasing transactions of Hypo Alpe-Adria Bank as well. Ultimately hoping that this exercise will shed a light also on what seems to be still not comprehended and thus operate as obstacles before the future growth of the leasing industry in the region. Further, these are unique evidences that would otherwise be doomed to fade away and disappear from the pages of legal history books notwithstanding that they could be useful not only in comprehending what went wrong with such major ventures as the Hypo Alpe-Adria Bank's expansion to the Balkans but might also be instructive to such emerging leasing systems as China that face the same dilemmas. 


\subsubsection{The 'Potisje' Leasing Project: the Origins and the Socio-Economic and Legal Environment}

The identity of the company in question is of little importance for our analysis save that obviously it was inferior to the Hypo Bank in all respects, not only financially but also as far as exposure to leasing as a sui generis business model, and generally knowledge on leasing, was concerned. Suffice to say only that its name was 'Potisje' 45 [hereinafter: 'Potisje'], it was for the Western Balkans a larger, non-private, export-oriented company, the main product of which were various types of lathes of varying sizes ${ }^{46}$ - or more precisely - equipment. In other words, the Potisje leasing project was a form of equipment leasing. All the leasing contracts that had been concluded involved these products in various combinations (i.e., one or more units of lathes, the same or differing types and sizes). The company does not exist anymore though the metal industry survived in the municipality it used to be seated in the Province of Vojvodina in the form of a few privately owned enterprises.

As far as the origins of the idea that made Potisje experiment with 'leasing' are concerned, three main factors ought to be mentioned. First, on the macro-economic level, this was the above-sketched changed business and legal environment. This generated some sort of euphoria and the concomitant quite sudden outbreak of interest in entrepreneurship, including the desire to transplant and learn from best western practices. Leasing seems to have been presumably the most well-known candidate for transplantation in those days in the entire post-socialist region.

Undoubtedly franchise could be mentioned as the other such success story besides leasing. The two, however, differ significantly in many respects. In particular, as the franchise market has remained dominated up until today by foreign franchise systems in most jurisdictions in CEE, the strategically and financially stronger US and Western European franchisors have been in the position to bring in their business models and impose their contracts on local franchisees. Franchise, in other words, managed to survive as an a-symmetric contract in case of which the balance between the parties normally being heavily tilted for the benefit of

45 The Potisje lathes are still used all over the world. Hence, images with the insignia 'Potisje' are still available on the Internet, (https://www.google.hu/search?q=potisje+lathe\&tbm=isch\&source=iu\&ictx=1\&fir=BtT_aeuPNeEm0M\%253A\%252Cyr2gPf-T1WVBdM\%252C_\&usg=__Q_3yzn7ST6yXRpmyX11EbXP8zFA\%3D\&sa=X\&ved=0ahUKEwjT6oXV7NTYAhUCWhQKHez1Dx8Q9QEIKjAB\#imgrc=BtT_aeuPNeEm0M:, 13 January 2018).

46 Lathe (in Serbian and Croatian: 'strug,' in German 'Drehmaschine,' in Hungarian 'eszterga,' in Italian 'torno'). 
the franchisor. ${ }^{47}$ Additionally, franchise has managed to survive unregulated in quite a number of countries of the region up until today. As opposed to that, leasing had a completely different fate. First and foremost, leasing is today normally already regulated in CEE (and much of Europe), moreover, more extensively compared to franchise. Yet while the lack of protective regulation makes the franchisees unprotected and vulnerable in the region, then the inefficient enforcement of leasing laws is what shifts the balance normally against the lessor. In other words, while in most cases it is the franchisee who could be identified as the weaker party in the region's countries, that cannot be unequivocally claimed for lessees; especially non-consumer lessees, who thanks to inefficient enforcement systems can easily abuse their rights.

Secondly, before the reform of secured transactions systems of the region's countries occurring roughly from the mid-1990s on and the domestication of leasing, credit was hardly widely and cheaply available in this niche of Europe. This was first and foremost due to the underdeveloped security laws of these jurisdictions where typically only possessory pledges and real property mortgages were the only known proprietary (in rem) security devices. While possessory pledge has always been ill-suited to modern business because it does not allow the debtor to possess and operate the collateral (e.g., a lathe or another machine) to generate income from which to repay the loan, a mortgage on buildings or land (especially in industrial zones) were hardly assets for which deep markets existed. Leasing was an excellent candidate for filling the vacuum.

Last but not least, the Company's very mundane reason was the need to generate more income by increasing the number of sold units of lathes (the main product of the company in question). It was presupposed that the new business vehicle - leasing - will attract more customers than the earlier used contracts, typically versions of instalment sales contracts paid by bills of exchanges ("menica"). This presumption departed from the simple idea that to many company directors and sales personnel already has heard about the good sides of leasing, or they could have relatively easily acquire the necessary information about it. However, the key psychological factor was that the dominant perception was that leasing works very well in western economies. In fact, as the recollections of the author of this paper go, the marketing strategy did work and did produce good results though only until the winds of the Balkan wars reached the market.

47 On franchise asymmetry see Tajti, T., 2015, Franchise and Contract Asymmetry: A Common Trans-Atlantic Agenda?, Loyola of Los Angeles Int'l \& Comparative Law Review, vol. 37, no. 1, pp. 245-274. 


\subsubsection{Structuring the Potisje Leasing Transactions}

The underlying leasing contracts followed the same pattern, given that they were structured after a few German and Austrian leasing contracts acquired from partners from these countries and presumably also through the local chambers of commerce. Their key features of relevance for our analysis were the following. Before embarking on their listing, it ought to be highlighted that these features are visible from the files of two out of the three Potisje Leasing cases, ${ }^{48}$ the copies of which are in the possession of the author.

First, the designation of the contract relied on varied. While initially the local language term for 'lease' was used - the name of the contract was in Serbian language "Ugovor o davanju mašine na privremeno korišćenje zakup" 49 - later the English-originated term was already used. In the latter phase thus the title of the contract in Serbian language read 'Ugovor o Lizin$g u .50$ The variation was obviously due to the fact that leasing was an innominate contract at that time and there was a risk that the use of the English language-originated term might cause interpretative dilemmas both in and outside courts. This was a major issue especially in the initial years of the introduction of the new business pattern. We will refer to these conveniently as the first and the second-generation Potisje leasing contracts.

Secondly, both the first and second-generation contracts were concluded as instalment sales contracts (often for 12 months) and provided for the lessee acquiring title (ownership) upon the timely and due fulfilment of all obligations from the contract. There were variations in this respect as well, as one of the contracts foresaw that title is transferred without any additional payment, ${ }^{51}$ the other gave the option to acquire title contingent on the payment of an extra half instalment. ${ }^{52}$ While in the

48 The court file numbers of the three cases are as follows. For ease of reference, we will refer to them as Case A, Case B and Case C. The case file number with the Economic Court of Subotica of Case A, defendant from Aleksinac, was PS. 5481/91. The case file number with the same Court of Case B, defendant from Aleksandrovac, was PS 5946/91. Finally, the case file number with the same Court of Case C, defendant from Kragujevac, was PS 74/96. As an appeal was filed in Case C, the court file number of the Appeal Court - the Higher Economic Court of Belgrade - was Pž 7729/96.

49 See Case B on the files with the author. This title in English would be 'Contract on Transfer of a Machine for Temporary Exploitation - Lease.'

50 See Case $\mathrm{C}$ on the files with the author. This title in English would be 'Leasing Contract.'

51 Case C, article 9.1. of the underlying Leasing Contract No. 132-02-1103/MP concluded on $7^{\text {th }}$ of October 1994.

52 Case B, article 10 of the underlying Contract on Transfer of a Machine for Temporary Exploitation - Lease No. 132-02-3021/GP-90. 
first case the formal requirement for the effectuation of the title-transfer was declaration of the transfer in a separate document, in the second case a separate sales contract should have been executed..$^{53}$

The third interesting point relates to the securities employed. Namely, the drafters of the first-generation contract that was named as 'Contract on Transfer of a Machine for Temporary Exploitation - lease' (Case B) included no clause on retention of title (ownership) (ROT) to the contract. This obviously because the drafters were of the opinion that actually the contract is nothing else but a true lease, where it is the normal duty of the lessee to return the possession over the lease upon expiry of the contract. As opposed to that, to the second-generation 'Leasing Contract' - already using the English-language originated term 'leasing' - retained ownership clause was already added. ${ }^{54}$

What is interesting that besides retained title, this clause in the second-generation leasing contract foresaw other protections of the lessor's ownership as well. Concretely, the duty of the lessee to take all actions necessary to protect the title (ownership) of the lessor, the right of the lessor to police $^{55}$ the object of leasing and check its appropriate use at any time, as well as the duty of the lessee not only to indicate in his books that the object of leasing is owned by the lessor but also to post signs on the object of leasing displaying who the rightful owner is. ${ }^{56}$ While the 1994 , second-generation Leasing Contract provided for a bank guarantee to be provided for by the lessee, it is doubtful that this requirement was implemented at all given that bank guarantees were expensive in those days as well.

Fourthly, only the 1994, second-generation Leasing Contract required the lessee to insure the object of leasing on its own account against all risks. ${ }^{57}$

Fifthly, both contracts provided for return of the objects of leasing in case of breach or expiry without exercising the option to purchase. As self-help repossession has, neither been known, let alone could be legally employed in those days, the respective provisions presumed a sort of amicable return of the machines. More concretely, in the first-generation

53 See article 10(a) of Case B and article 9.1. of Case C.

54 See article 4 of the underlying Leasing Contract in Case C.

55 Policing the collateral is an expression used in the US and it entitles the lessor (or secured creditor) to check the object of leasing (or collateral) in the hands of the lessee from time to time by paying visit to the premises where the asset is located. Today, often companies that provide 'collateral management' services are hired to visit the lessee (debtor) to check this.

56 See the subsections of article 4 of the underlying Leasing Contract in Case C.

57 See article 5 of the underlying Leasing Contract in Case C. 
contract the transport (return - "povraćaj") was to be organized and financed by the lessor though with the right to ask the lessee to recoup these expenditures. As per the somewhat more detailed provisions of the 1994, second-generation Leasing Contract, in the first step it was the lessee who should have returned the object of leasing to the premises of the lessor at its own costs and bearing all the concomitant risks. Only if the lessee would not fulfil this obligation of his was the lessor expected to step in and organize the return, however, again at the cost and risk of the lessee. ${ }^{58}$ From the information the author of this paper received about these cases, these provisions have proved to be dead letters on paper because none of the lessees was willing to voluntarily return any of the machines. Furthermore, in most the cases was court enforcement of these provisions successful either.

Unfortunately, the problems with "return" of the object of leasing outof-court or through the court bailiff system as showed by these early cases and experiences have survived up until today in many of the region's system. The lessor's right to repossess, or what rights the lessor has as far as the possession of the object of leasing is concerned, remain consequently one of the most contested issues in this niche of Europe. The impotency of the court-bailiff system of those days, however, cannot be supported by concrete empirical evidences given that after a few attempts the counsel of the Vojvodina Company have not even tried to resort to courts for repossession. Instead of asking the courts to adjudge that the lessor has a right to return (repossess) the object of leasing, courts were rather requested to award the unpaid instalments with some interest, and expenditures because these could be more easily collected from the bank accounts of lessees (even if with some delay).

\subsubsection{The Potisje Leasing Contracts in Courts: Excerpts from Judgments}

As many of the Potisje leasing contracts ended up in courts, even the few judgments may be instructive on two questions of key importance to leasing law: the perception of leasing as a new-comer contract and the rights of the parties upon default or breach of the contract. Unfortunately, the full texts of judgments are available only in two out of the three leasing cases mentioned above. These are telling on three specific and on one general point. On the one hand, they readily confirm that, indeed, while courts were quite familiar with leasing as a newcomer business vehicle, the lack of rules similar to the common law doctrine of election of remedies led to differing positions on what the rights of parties to leasing contracts

58 See article 9.4. of the underlying Leasing Contract in Case C. 
were upon default or breach. As it will be discussed in a bit more detail below, the latter remains an issue up until today though the increasing number of statutory interventions obviously has generated a more predictable legal framework. The dilemma is rather whether the right balance has been struck by the detailed rules on the parties' rights in these new leasing laws.

Yet perhaps the most valuable conclusion that may be drawn from these idiosyncratic early cases is that the judges adjudicating these cases did display proper understanding of leasing, especially if taking into account the quite rudimentary nature of leasing scholarship in those days, the scarcity of pertaining scholarly publications, as well as the extreme hardship one had to face in those days in acquiring quality sources on foreign law or foreign-originated legal institutions of the leasing-sort. Additionally, the decisions display also a dose of judicial activism and willingness to go beyond the four corners of the laws existent in those days; something not necessarily being a characteristic of courts in the region even today.

As far as the nature, or definition of leasing, is concerned, the following should be highlighted from the judgment of Case $\mathrm{C}$ that went through two appellate levels. As a starting point, here two pieces of lathes were delivered under the contract and although the lessee duly paid some of the instalments, eventually it defaulted before the expiry of the contract. The first instance commercial court defined leasing as "a contract in case of which the lessor promises to transfer into the possession of the lessee the object of leasing for a fixed period of time, for general use or for a specific business, and the lessee obliges itself to pay a specific charge (rent in the form of instalments) under the condition that upon the expiry of the contract it must return the object of leasing, unless the contract gets prolonged or it purchases the object of leasing." It is not documented based on what did the court reach this interpretation.

The court then consistently applied this position because it rejected the defendant's claim according to which it acquired ownership on one of the two lathes delivered to it through partial payments. It claimed that the aggregate of instalments paid was sufficient to cover the price of one of the machines (but not both of them). In other words, the court was not willing to disregard the explicit provision of the contract according to which ownership (title) could be acquired only upon due fulfilment of all the obligations from the contract. This position was supported also by the Appellate Commercial Court of the capital, Belgrade.

Both courts in the case ordered the defendant (lessee) to return (transport back) the machines to the address of the lessor, at its own costs and 
by organizing the transport and the related logistics within 15 days from the finality of the respective decisions. Although the traditional warning was also added that if the lessee fails to do that then the court (bailiff) is to enforce the order, in none of the cases has that occurred. This because the court bailiffs were in those days, neither equipped with the necessary equipment and appliances, nor accustomed to repossess and face all the corollary inconveniences or conflicts. This deficiency of the system exacerbated with the arrival of the Balkan wars. Albeit important changes occurred in many countries of the post-socialist region in the transitory phase and many have privatized their bailiff systems, repossession remains the number one problem, both for the leasing industry being interested in quick repossession based on the retained title (ownership) and the lawmakers that worry for the possible concomitant abuses and overreaches.

It ought to be added that other problems have been faced by the lessor (Potisje, the company from Vojvodina) when trying to enforce its rights the same period. These unfortunately cannot be documented by court writs. Three such hurdles of lessors (and lessor-plaintiffs) should be mentioned as problems that may emerge in other emerging legal systems as well; especially in those with low level of the rule of law. First, although some of the leasing contracts provided for the lessee's obligation to post signs in the premises where the leasing object was located, as a rule this obligation was not adhered to by lessees. The main reasons were that policing the object in the possession of the lessee by the lessor was, typically neither provided for in the model Western European leasing contracts, nor was a usual pattern of doing business in this part of Europe. Thus, an unannounced visit to check whether the signs have been posted, or the retained title was properly noted in the books of the lessee, has not become a routine of the lessor from Vojvodina. One may presume as well that the strong possessory protections characteristic to civil laws of the region would not allow even for such modest versions of out-of-court enforcement of contractual obligations.

This was partially due also to the second problem that concerned proving ownership of the lessor. Namely, in those days title (ownership) not only on lathes but on most movables were not subject to any kind of registration with a publicly accessible register. Consequently, there was no document that would have authentically proved ownership. If the lessee failed (as it normally happened) to show on its books the ownership of the lessor and refused to post signs proving that, then the only document that the lessor could use to prove its retained ownership was the leasing contract. Based on this, however, the courts were hardly willing to issue provisional measures and even if they were willing to do that the same 
impotent court bailiff system should have been resorted to enforce it. Needless to say, although it was attempted in the Potisje leasing cases, the police refused even to take a look at the leasing contracts to determine who has ownership. These unhappy features of the system readily prove the legitimacy of such registration systems that record clearly and unequivocally the retained title (ownership) in leasing contracts.

Last but not least, admittedly not typical to leasing only, courts were often simply not capable to deliver even their summons or other writs during the civil proceedings; let alone ensure prompt return of the object of leasing. The closer the winds of Balkan wars were, the more problematic these became. Thus, contrary to the source jurisdiction, the United States, where the normal sequence in case of lessee's default is prompt outof-court repossession of the collateral that may but must not be followed by litigation, in the Balkans enforcement of lessor's rights meant rather years spent with litigation during which the possession of the leasing object remained with the lessee until the court bailiffs managed to repossess them typically only based on the final judgment and executive writ.

\subsubsection{Lessons, Dilemmas and Questions}

As one could conclude from the above, the Potisje Leasing cases highlighted quite early dilemmas related to, at least, three key building blocks of leasing law: first, the definition, legal nature and features of leasing, as well as the concomitant question of which types of leasing should be nominated and regulated; second, the importance of repossession rights, and third, a set of problems that is corollary or stems from what is known in common laws as the election of remedies doctrines. In the part to follow, we will take a look at each of these issues from the perspective of comparative law, or what developed common law and civilian legal systems offer as responses to these.

In doing that, besides speculating on whether the related surviving deficiencies of the laws of the region could have contributed to the fall of the Hypo Bank, we will try to see whether the various solutions offered by developed systems could create incentives for the growth of equipment leasing in the region as well? We will reflect on this admittedly complex interdisciplinary topic through the prism of two interrelated issues: the policies justifying the recognition of the so-called 'hell and high-water clauses' and importance the support of the judiciary plays in boosting the industries. Namely, as the experiences of the US show, both are crucial preconditions for the spreading of finance lease and through that also of equipment leasing. 
The position of this paper, in other words, is that creation of a regulatory environment that would be conducive to the growth of the local leasing industries primarily requires appropriate answers to the above identified questions and dilemmas.

\subsection{EXPORTED LEGAL ENGINEERING: THE HYPO ALPE-ADRIA BANK ON THE BALKANS AND ITS FALL}

Unfortunately, in-depth analyses on the causes of the fall of the Hypo-Alpe Adria Bank, not long ago the fifth largest bank of Austria, do not seem to be available publicly; especially in English language. ${ }^{59}$ This applies also to the various financial reports prepared as part of the winding down and bailout process of the Bank that normally restrict themselves to select key facts and data that only indirectly (if at all) hint at the possible causes. ${ }^{60}$ In addition to that, the financial documents prepared by the legal successor of the Bank - the HETA Asset Protection AG - should be read with having in sight that as per the applicable securities regulations these documents are not expected to tell the full story. ${ }^{61}$ One may safely presume as well that given that the topic is still politically sensitive in Austria, it is not rewarding to further scrutinize what went wrong more concretely. Consequently, the available scholarly papers tend to remain silent on the causes and even if they do comment they do not go beyond a few short remarks. ${ }^{62}$ Part of the story is that politicians and journalists primarily point to corruption as the main (if not the only) cause of the Bank's fall. ${ }^{63}$ Consequently, the defects of the leasing model employed by

59 The exception seems to be the book of Müller, M., 2014, Bankensanierung statt Bankinsolvenz: Sanierungsablauf am Beispiel der Hypo Alpe-Adria Bank AG, Hamburg, Diplomica Verlag [Hereinafter: Müller, M., 2014.]

60 See, for example, the HETA Asset Resolution AG financial reports for the past years, (http://www.heta-asset-resolution.com/en/content/financial-reports-presentations, 5 January 2018).

61 For example, as displayed on the first page of the 2015 HETA Asset Resolution AG Annual Financial Report, this was concretely section 82(4) of the Austrian Stock Exchange Act ("Börsegesetz" abbreviated as BörseG).

62 See, e.g., Kalss, S., 2010, Measures by the Austrian Regulatory Authorities in Response to the Financial Market Crisis, European Business Organization Law Review 11, pp. 527-548, stating that the collapse of the Hypo Alpe Adria Bank was due also to the fact that the Bank "maintained extremely extensive business relations with unreliable business partners, some of which are even said to be part of mafia-like organisations." Id. at 529. [Hereinafter: Kalls, S., 2010].

63 See, e.g., Srdoc, N., Austria's Hypo Group Alpe Adria: Collapse of the Rule of Law in Europe's Largest Post-WWII Baking Scandal - Billions Missing, Culprits still at Large, Huffington Post, 13 October 2017 issue; (https://www.huffingtonpost.com/entry/ hypo-group-alpe-adria-collapse-of-the-rule-of-law_us_59e06ab8e4b003f928d5e5c6, 
the Bank that otherwise presumably were one set of the factors contributing to the generation of the problematic leasing portfolios of the Bank remain overshadowed by the corruption narrative. This notwithstanding that leasing prong was one of the, if not the, most important segment of the Bank's activities.

The vacuum could partially be attributed also to the fact that empirical case studies and exploitation of non-traditional sources of law is still largely foreign to Austrian legal scholarship dominated by strong positivistic traditions leaving their imprint on the focus, nature and basically all features of Austrian scholarship. The same could otherwise validly be claimed also for the scholarship of all CEE post-socialist countries, including the Western Balkans.

However, admittedly the fall of the Bank is attributable to more factors from among which this article aims to focus on only one: the misunderstanding of leasing as a newcomer transaction on the Balkans (and basically the entire post-socialist region of Europe). That leasing as a sui generis transaction has contributed to the misfortunes of the Bank was shyly noted by some investigative journalists but this particular question has so far escaped the attention of legal scholars. As one of the very few articles in the Wall Street Journal briefly noted "[The bank] was nationalised after running up huge losses in the Balkans. The group incurred a net loss of Euro 1.58 billion last year, thanks to problematic leasing and cross-border financing portfolios, and expects to make provisions for losses of about Euro 1 billion in 2010. [...]." ${ }^{64}$ [Emphasis added.] Still, Müller, found it important to distinguish the two main business segments of the Bank's activities, which besides banking, indeed, was leasing. ${ }^{65}$

This article's goals are therefore modest: it does not intend to deal with the corruption and money laundering-related aspects of the case, nor with the bailout of the Bank; a deeper analysis of these, otherwise clearly challenging and interesting facets of the case, should be left to other scholars. This article aims solely to focus on the question whether the Bank so heavily exploiting the newcomer device of 'leasing' has really understood the true nature of leasing? Likewise, is leasing already truly properly

5 January 2018). Croatia seems to stand out because it sentenced its former PrimeMinister (Ivo Sanader) for accepting bribes (among others) from the Bank. The figures mentioned vary. Tom Lansferd's Political Handbook of the World 2014 (Sage \& CQPress, 2014) mentioned $€ 545,000$. Id. at 349 . Sanader was sentenced to ten years of prison, what was then reduced by the Supreme Court of Croatia to eight and a half years. However, for procedural errors, the decision was annulled. Retrial is expected.

64 Bryant, C., Finance Probes Stretch Limits of Justice System, WSJ, 22 Oct. 2010 issue, at 3 (special supplement on Austria).

Müller, M., 2014, p 6. 
comprehended by others perusing this business vehicle today as well? More precisely, whether it is known what internal and external factors must be fulfilled to make leasing work even in such emerging systems where the rule of law is significantly lower than in such high rule of law countries as Austria or the United States?

Last but not least, it ought to be added that this paper is not a piece of writing from under the pen of investigative journalists disguised as a scholarly article and therefore it is not an attempt to reveal some so far unreported insider information about the case. Rather, the focus is solely on those leasing-related legal questions that might have escaped the attention of the Bank or were misunderstood by it and yet which survive in the region until present time.

\subsubsection{The Hypo-Alpe Adria Bank Saga in a Nutshell}

\subsubsection{The Glory Years: Growth, Expansion, Internationalization}

In addition to criminal lawyers, political scientists and other interested in corruption, money laundering, the ascent and the fall of the Hypo-Alpe Adria Bank is primarily a topic on bank bailouts, governance of banks and such corollary issues as systemic risk or sovereign insolvency. Obviously, the leasing prong of the Bank's activities did not exist in a vacuum and therefore hardly could it be fully separated from these. Yet given our focus on leasing - or the commercial law aspects of the case - it suffices to describe only those key developments in the more than century-long history of the Bank (though clearly focusing on the post-2008 agonizing years of the Bank) that would provide the reader with sufficient information on the true dimensions not only of the Bank and its operations but also on the magnitude of the risks the fall of the Bank generated for one of the richest countries of our contemporary world: Austria and one of its federal units, the State of Carinthia. Needless to say, in this respect special importance must be attributed to the Bank's leasing operations in the Balkans.

The biography of the Bank starts with year 1896 when the regional bank Landes- und Hypothekenanstalt was established in Carinthia. ${ }^{66}$ Notwithstanding the long existence, its international expansion and a parallel diversification of its activities of central interest to us began only in 1990, which was also the year when its expansion to the Alps-to-Adria region set out. It is an important fact that this expansion was supported by the guarantee of the State of Carinthia and it is this guarantee that later almost

66 See, e.g., HETA Asset Resolution AG, Annual Financial Report 2015, p. 4. [Hereinafter: HETA 2015]. 
bankrupted this State. This scenario, that would have been a shock for Austria, was avoided eventually thanks to the involvement of the federal government and the willingness of the Bank's creditors to take the haircut (i.e., losses) proposed by Carinthia.

As part of the expansion, the Bank morphed from a regional to a true international financial group, among others by becoming one of the main foreign banks on the markets of virtually all Balkan states and beyond (in particular Germany, Hungary and Italy - and somewhat later Ukraine in 2007). This required transformation into a group of companies, with subsidiaries formed for all the targeted countries and creation of a holding company - the Hypo Alpe-Adria-Bank International AG - in $2004 .{ }^{67}$

Undoubtedly leasing was chief among the techniques behind the expansion. The leasing prong of the Bank's activities deserves special attention because it produced a spectacular growth within only of a few years. It started with the formation of the subsidiary Hypo-Leasing Kärnten $\mathrm{GmbH}$ (Ltd) in the city of Klagenfurt in 1990 and then leasing-subsidiaries in the targeted countries. For example, while the leasing subsidiaries were formed in Slovenia and Croatia in 1992 (after Italy), they emerged in Hungary and Montenegro in 2005, which were later followed by the ones in Serbia and Bulgaria and so on. Leasing was employed by these entities to allow for acquisition of almost all kinds of assets from motor vehicles ("KFZ Leasing or Kraftfahrzeug Leasing"), ships, aircraft, equipment through immovables. ${ }^{68}$ It is indicative that leasing generated $38.3 \%$ of the group's income, for example, already in year 2005.

\subsubsection{The Global Financial Crisis of 2008: Fall and Partial Rescue of the Bank}

This period of unprecedented growth was then broken roughly at the time the spillover effects of the 2008 global financial crisis reached the region. Some reports, indeed, ascribe the fall of the Bank to this though it is questionable whether such a position is tenable, among others, because the unearthed non-negligible corruption and money laundering scandals clearly could be pointed at as major factors as well. ${ }^{69}$ On top of all that come the uncharted yet possible devastating effects of the problematic leasing portfolios. Given that the Bank introduced leasing essentially as a new business vehicle on the Western Balkans, the risks concomitant to introduction of a new business model presumably are partly to blame, too.

67 For a short overview of the history of the Bank see Müller, M., 2014, p. 10 et seq.

68 Müller, M., 2014, p. 9.

69 Kalss, S., p. 529. 
The winding up part of the saga is complex yet instructive for all interested in bank bailouts and bail-ins yet are of little relevance for our discussion on leasing save that the Balkan units, inclusive the leasing ventures, of the Bank were sold to third parties. Whether this could be taken as an indirect indicator that therefore leasing properly functioned in the affected countries is not clear; first and foremost because the leasing prong's results hardly could be fully separated from those of the other activities of the Bank.

The rescue began with the Republic of Austria (the federation) becoming the sole owner of the Bank in $2009 .{ }^{70}$ Yet the banking license of the Bank was terminated only in 2014 as years were needed for a proper wordwide asset review and to determine the value of the asset shortage. The estimates from 2015 talked of asset shortage in the range of 4 to 7.6 billion Euros.

Thereafter a separate act was passed - the Federal Act on the Constitution of a Wind down Entity (GSA) ${ }^{71}$ - for effectuation of the prolonged liquidation of the Bank. As a result, two units were formed: the wind down and the reprivatisation unit.

The latter - named as HETA Asset Reprivatisation AG - included the assets and debts of the Central and Eastern European network of subsidiaries (including the Western Balkans jurisdictions). The Balkan unit eventually was sold in 2014 to the EBRD (20\%) and the Advent International private equity company ( $80 \%) .{ }^{72}$

Unfortunately, the faith of the winding down unit has not been as straightforward as that of the reprivatization-oriented one, as we will see from the next section below briefly sketching the proceedings before the EU Commission and the Austrian Constitutional Court. For our purposes, it suffices to highlight here only, first, that the designations have changed here as well and the name of former 'Hypo Alpe-Adria-Bank International AG' changed to 'HETA Asset Resolution AG' (normally referred to under the shorthand designation of HETA). ${ }^{73}$ Further, although the statutory mandate of the winding down unit was to 'ensure orderly, active and best possible exploitation (portfolio wind down),' this included also the right to make banking and leasing transactions to the extent not conflicting with the mandate. ${ }^{74}$

70 HETA Annual Financial Report 2015, p. 4.

71 Federal Law Gazette I 2014/51.

72 See, e.g., Shields, M., Austria sells Hypo Balkans network to private equity firm Advent, Reuters (23 December 2014), (Austria sells Hypo Balkans network to private equity firm Advent Michael Shields, 6 January 2018).

73 HETA Annual Financial Report 2015, page 4. The name-change was effective from 31 October 2014.

74 Section 3(1) of GSA. See also HETA Annual Financial Report 2015, page 4. 


\subsubsection{The Bank Rescue Measures before the EU Commission and the Austrian Constitutional Court}

The heavy involvement of the federal government triggered as well state aid investigations of the EU Commission that ended with a decision in early September 2013 approving the plan of the Austrian government to wind down the Bank. ${ }^{75}$ As the related Press Release put it, the GSA "is compatible with the EU crisis rules applicable to state aid to the banking sector." 76 The Commission cleared (approved) as well the earlier 'public support measures' to the Bank. ${ }^{77}$

Notwithstanding the green light from Brussels, however, the Act could not be implemented because proceedings have been commenced also before the Austrian Constitutional Court ("Verfassungsgerichtshof"), ${ }^{78}$ which ended with proclaiming the Act unconstitutional in July 2015. ${ }^{79}$ The Act was repealed in its entirety and no deadline was set for its correction. From the 154-pages long, German language decision of the Constitutional Court, only the following two points ought to be highlighted here, given that these were the key reasons behind the decision of the Court.

First, although the legislator can pass laws that treat various classes of creditors differently, the solutions of the GSA infringed the fundamental right to the protection of property. Namely, the way the GSA made such differentiation was unconstitutional because it took an arbitrary date (30 June 2019) as a dividing point for imposing a haircut (losses) only on some but not all creditors. More concretely it foresaw that creditors whose claims mature before this date lose their claims completely - the claims are deemed to be expired - and the claims of those maturing after not. The latter class' claims were foreseen not to be affected by the GSA. Secondly, it was also foreseen that the guarantee of the State of Carinthia ${ }^{80}$ expired as well vis-à-vis the losing but not respective to the other class. ${ }^{81}$

75 EU Commission Press Release, State Aid: Commission Approves Plan to Orderly Wind Down Hypo Group Alpe Adria as of 3 September 2013.

76 Id.

77 As listed in the EU Commission Press Release (2013), the public support measures included: $1 / € 2.85$ bn in capital or guarantees on capital; $2 / € 300 \mathrm{~m}$. in guarantees on assets, and $3 / € 1.35 \mathrm{bn}$. In refinancing guarantees.

78 The Constitutional Court case numbers are: G 239/2014-27, G 98/2015-27.

79 See the Constitutional Court Press Release (in English) as of 28 July 2015 in case G 239/2015 ua.

80 The insolvency of the Bank would have triggered about $€ 12 \mathrm{bn}$ in loan guarantees given to the Bank. See Shotter, J., Austria Bad Bank Plan Risks Breaking Bloc's Budget Limit, in: Financial Times, 11 March 2014 issue, page 3.

81 See the EU Commission Press Release as of 2 September 2013. 
After this overview of the Hypo saga, let us turn to analysis of those major dilemmas that have caused headaches to the Company from Vojvodina experimenting with leasing and that might have contributed as well to the misfortunes of the Bank. These will be referred here to as the 'key building blocks of leasing law' because they are a sine qua non for forging such leasing laws that would boost local leasing industries.

\section{The Key Building Blocks of Leasing Law and the Corollary Surviving Dilemmas IN THE WESTERN BALKANS}

\subsection{THE PROLONGED DILEMMAS WITH THE DEFINITION OF 'LEASING'}

\subsubsection{Misconceptions about the History and Geography of Leasing}

While there is a common understanding that 'leasing' stems from the US and some authors add also the 'Bell Telephone' business model as presumably the first predecessor of contemporary leasing, ${ }^{82}$ many other important details are normally missing from the history-devoted paragraphs of leasing chapters in textbooks, articles and other pertaining publications. The incomplete story inevitably distorts the picture. That modern form leasing began to spread to Europe and the rest of the word from the US starting somewhere in the 1950s, however, one should not doubt: the United States Leasing Corporation established in San Francisco in 1952, ${ }^{83}$ as the first modern leasing company, is to be referred to in that respect.

Two points must in particular be clarified or commented upon. First, the 'Bell telephone' business model - offering telephones not for sale but exclusively for lease - as the most typically mentioned predecessor of leasing could have successfully worked because of the monopoly Bell enjoyed for the decades to follow the patenting of the telephone in $1876 .{ }^{84}$ As Gilmore superbly put it, forcing customers to lease instead of

82 See, for example, Vasiljević, M., 1995, Trgovinsko pravo, $4^{\text {th }}$ ed., Belgrade, Savremena administracija, p. 678.

83 See, e.g., Stanford, M. J., 1987, Rapport explicatif sur le projet de convention sur le Credit-bail international, Uniform Law Review, vol. 15, no. 11, pp. 168-365 (Jan.), page 195 .

84 The Bell Patent Association, renamed soon upon formation to the Bell Telephone Company, began offering the telephone - patented in 1876 - already in 1877 for public use. The telephones could be leased for an annual fee of $\$ 20$ if 'for social purposes', 
purchase was possible only with respect to a handful of "[...] well-known type of arrangement [s], [involving] a manufacturer of specialized equipment, who has, with or without the aid of the patent laws, obtained monopoly, or near monopoly, [that created for him such an] advantageous a position that [he could] refuse to sell his product at all but instead lease it to users: familiar examples [included] show machinery, I.B.M. machines and, for that matter, telephones." 85 In other words, there was no need for any registration of these leases, or their objects, because it was generally known not only who owned the equipment but also that a telephone in private hands was on lease.

Secondly, the historic pages on leasing often do not go back in time more than the mentioned Bell telephone business model. Yet for understanding why do some major legal systems treat leasing as a secured transaction akin to pledges or chattel mortgages (registered pledges) and why has leasing become subject to registration in some states in US and other common law systems and beyond, one should go back as far as the 1820s when the first chattel mortgage statutes were enacted first in the Eastern seaboard states and later on in the rest of the US. ${ }^{86}$ Namely, these early statutes from the early years of industrial revolution when movables more valuable than real property began to appear, worried about ostensible ownership and secret liens (or false wealth), foresaw the possibility of "pledging" these valuable tangible movables by subjecting them to registration in public registers following the logic of real property mortgage law. The problem that made businessmen, bankers and their counsel experiment was that formalism was at its peak in those early decades of the $19^{\text {th }}$ century and consequently it was easy to make a mistake even unwittingly and lose the priorities or otherwise as a consequence.

In a decade or so the reaction was that - in order to avoid the pitfalls of chattel mortgage legislation - the chattel mortgage contracts were named in practice first as conditional sales and somewhat later were "dressed up ... in language of lease in which seller [became] 'lessor', buyer ... [lessee] and the payments to be made ... [rent]." 87 In other words, this ramification of the road leading to modern time leasing could admittedly be described also as fraudulent as it was a method to bypass the law in force. Yet as over time conditional sales became also subject to registration and other formal requirements, eventually the same formal requirements

an amount that was doubled if for business purposes. See Stefoff, R., 2006, The Telephone, New York, Marshall Cavendish, p. 52. 
were imposed on other title finance transactions as well, including leases, what made out of such conditional sales and leasing transactions legitimate creatures of the law.

However, these non-salutary pages in the history of leasing hardly could lead to the conclusion that therefore leasing was nothing more than fraud and that registration was imposed solely to combat this specific form of fraud. This because in the latter half of the $19^{\text {th }}$ and much of the $20^{\text {th }}$ century distinct industries appeared all "living from" this or that version of leasing. So much so that over time not only banks and their affiliates but independent leasing companies appeared on the US markets. These are today normally referred to as non-banking financial organizations. Moreover, registration became the regular response of the lawmakers whenever a new security device, or the kin of leasing, appeared on the market (e.g., the most recent rent-to-own contracts). Ultimately, however, conditional sales and leases were transformed into secured transactions and subjected to the same legal regime by the arrival of the UCC in the early 1950s; including registration (filing) in the same registers as chattel mortgages and other secured transactions.

If one takes a look at the late $20^{\text {th }}$ century development of German law that as well made out of various leasing transactions security devices though without subjecting them to registration - the rational that speaks in favour of bringing acquisition finance and other security devices on movables, rights and claims under the same regulatory roof should not be easily discarded. One may suspect that this is the next evolutionary phase that awaits most of the Western Balkans countries. Hungary, although not a Balkan country but otherwise sharing many things as far as leasing is concerned with these countries, was forced to admit as part of the third wave of reform of its security law in 2013 that registration of financial leasing transactions in the very same register in which 'charges on movables' are entered is a way to prevent bypassing of the latter system. Namely, before the changes introduced by the 2013 Civil Code - that introduced this rule - leasing was not subject to registration with any public register as opposed to the charges on movables that were introduced in 1996 with the help of EBRD and as such - similarly to the $19^{\text {th }}$ century US patterns often it was employed as a way to bypass the registration and the concomitant priority and enforcement laws. This Hungarian scenario from the post-1990 years was the same that had occurred in the US, as described earlier, in the $19^{\text {th }}$ century US.

Ultimately then today one could differentiate the following models of leasing law. The first group encompasses the US and all the other systems that embraced the functional approach forming the core of the Unitary 
System where leasing and other title finance transactions are treated as secured transactions and are subject to registration (called: filing) and other rules of secured transaction laws. Second, German law and its followers, where some versions of leasing are treated as sui generis secured transactions but without their constitution being contingent on registration; i.e., they come into being by mere inclusion into the underlying contracts. This contract clauses-based law is almost entirely court made law; or more precisely, legal engineering and innovative contract drafting given green light by courts. The third group of countries that do not make a secured transaction out of the hybrid leasing transaction but tolerates its separate existence is perhaps the most typical for the Western Balkans and the post-socialist countries. Here, more sub-variants of leasing laws should be distinguished, in particular according to the criteria of whether lex specialis has been brought for leasing and if yes whether the law covers more types of leasing or only one - typically which is financial leasing. Last but not least, there are still countries where there is no special law devoted to leasing and thus general contract law applies presumably with application of rules on nominated contracts resembling the most leasing contracts.

\subsubsection{Dilemmas Corollary to the Operating versus Financial Leasing Classification}

Presumably the most important classification of leasing transactions is the one to operating versus financial (or finance) leasing (or lease), at least in the Western Balkans and in the European post-socialist systems. This because normally this pair is taken as the starting point for regulating leasing in CEE as opposed to, for example, US law where for the UCC the true versus security lease is what comes to the forefront.

The perception of what the key features of operating versus financial leases are vary significantly from state to state. For our purses the definition of Dalhuisen is most appropriate, which stresses the 'financing aspects' of finance lease and adds that 'finance lease' is "a more generic term for all leases that include a financing element, whether or not subsequently characterized as a secured transaction or a conditional sale under applicable law." ${ }^{8}$ For better understanding what more concretely the 'financing' element entails, the ensuing discussion on hell or high water clauses should be resorted to primarily.

A few examples from the region might shed a light on the true dimensions of the discrepancies. For example, while the Croatian Leasing

88 Dalhuisen, J. H., 2016, Dalhuisen on Transnational Comparative, Commercial, Financial and Trade Law, vol. III $6^{\text {th }}$ ed., Hart, note 129 on page 229. 
Act and that of Bosnia and Herzegovina $(\mathrm{BiH})^{89}$ extends to both operating and financial leasing, in Serbia only financial leasing is subject to a lex specialis. This means, among others, that the duty to register does not necessarily extend to all types of leasing. The neighbouring country, Hungary's new leasing law enshrined into the 2013 Civil Code, similarly to Serbia, is based on the position that 'leasing' is limited to financial leasing only. 90 This because "the goal of the lessee [in case of operating leasing] is not acquisition of ownership on the object of leasing but, similarly to the [classical] rent (lease), only use for a limited period of time." ${ }^{1}$ Subjection of the newly nominated financial leasing in Hungary to registration - not in a separate 'leasing register' (which does not exist) - but in the register of charges on movables (i.e., security rights) already shows the maturing realization that leasing is very close to secured transactions. This is not the case for the time being in Croatia or Serbia, where separate registries exist for leasing and registered pledges.

A closer look at the statutory definitions may easily reveal further deeper differences. For example, the Croatian definition differentiates operating and financial leasing primarily based on the criterion whether the lessee has the contracted for option to purchase the object of leasing: in case of operating leasing the option is not agreed upon. ${ }^{92}$ As opposed to that, the Serbian act links the definition of financial leasing to more non-cumulative preconditions out of which the agreed upon right to purchase the object of leasing is only one of the many. ${ }^{93}$ Linkage to the option to acquire

89 Zakon o Lizingu (Službene novine Federacije BiH, br. 85/08, 39/00, 65/13 i 104/16), section 5(2).

90 Hungary had only two Civil Codes in its entire history. The first passed during socialism in 1956 was replaced by a new one only in 2013. One of the goals of the drafters, led by Prof. Lajos Vékás, was to nominate such newcomer successes as leasing, factoring and franchise. As far as leasing is concerned, however, only financial leasing is being by the Civil Code in Title XX, Chapter LIX, sections 6:409 through 6:415. Financial leasing has become subject to registration, if the object is immovable in the register of immovables, if the object is a movable or a right, in the register of charges (registered pledged). Vékás, L., (ed.), 2013, Commentary of the Civil Code, $1^{\text {st }}$ ed., (“ $A$ Polgári Törvénykönyv magyarázatokkal”), Budapest, Complex, p. 873. [Hereinafter: Complex Civil Code Commentary 2013].

91 Complex Civil Code Commentary 2013, p. 873.

92 Croatian Law on Leasing (2013), section 5(2) and (3). Besides the option the law adds other elements to the definition of financial leasing: $a /$ the instalment (rent rate) payable is based on the total value of the object of leasing; b/ lessee covers depreciation; $\mathrm{c}$ lessee may exercise is option to purchase the object of leasing at the price that must be lower than the remaining value of the object at that point in time; $d /$ the risks and proceeds corollary to ownership in most part are transferred onto the lessee.

93 Serbian Law on Financial Leasing (2003), section 2(3). The five non-cumulative preconditions are: 1 / the object of leasing is chosen/determined by the lessee; 2 / owner- 
ownership, for example, is not even part of the definition of finance lease in the United Kingdom, though this may be explained by the existence of the UK speciality acquisition finance instrument of hire-purchase. ${ }^{94}$

A company, that intends to do business across borders therefore should pay due attention to these differences given that the resulting rights and obligations of the parties may significantly vary from country to country notwithstanding the identical designations. Although the nuances in the definitions of course matter, as it will be seen from the discussion below on the hell-or-high-water clauses, equally if not more important is for the proper functioning and growth of local leasing industries whether financiers willing to finance acquisition of equipment can fully isolate themselves from warranty claims based on leasing laws. Unfortunately, even a cursory look at the latest generations of the region's laws could easily reveal that this important expectation has largely escaped the attention of local lawmakers. In other words, one may get the impression that the definitions end up being not only excessively complicated but that they miss the essence.

The great variety of definitions, often accompanied by a degree of obscurity that makes understanding the lawmakers' true intentions problematic, is partially to be ascribed to western laws that are consulted in the drafting process. Not infrequently the identity of the foreign consultants, the views and the background of the financiers of the reforms or language proficiencies are the reasons this or that model is only looked at - rather than a proper understanding of the essence of leasing, or its sub-variants. This notwithstanding that comparison of more systems' solutions and the views of different authors could yield better results.

For example, often the main advantage of leasing ${ }^{95}$ is explained by a more favourable tax treatment. This admittedly is an important factor to

ship on the object of leasing is transferred onto the lessee upon expiry of the leasing contract and due payment of all agreed upon instalments; 3 / lessee has the option to purchase the object of leasing upon payment of all instalments; 4/ lessee may prolong the leasing agreement; and $5 /$ the term for which the leasing contract is concluded is equal with the full, or overwhelming part of the depreciation period of the object.

94 According to UK law, "[a] finance lease is similar to an operating lease in that the company never acquires ownership of the asset, but the lease is for a fixed period of time, and the periodic payments made by the company include the capital costs of the asset, spread out over that period of time, as well as payments for hire." Yet the main reason is that - albeit "in a finance lease, the lessee has all the risks and rewards of the item [-] but cannot acquire it itself, as this would turn it into a hire purchase agreement." Quoted from Gullifer, L., Payne, J., 2011, Corporate Finance Law - Principles and Policy, $1^{\text {st }}$ ed., Oxford and Portland, Hart Publishing, the main body of text and note 218 on page 41 .

95 The developments in the United Kingdom could as well corroborate these points. Namely, until the Finance Act 2006, the chief advantage of finance lease, "as opposed 
be reckoned with. Yet what is often forgotten is what Gilmore warned us already in 1965, which is that "the tax advantages could only be guaranteed good until the next revision of the tax regulations, if that long." ${ }^{96}$ His warning notwithstanding, especially leasing-related publications not written by lawyers, are regularly filled with accounting and tax-linked justifications that make legal considerations seemingly unimportant. ${ }^{97}$

What may be idiosyncratic to the Western Balkans and similarly situated emerging leasing systems and laws, where financial literacy is low and even the staff of regulatory agencies is struggling with coming forward with the right explanations, is that the over-complicated, too formalistic definitions may result in non-transparent and unpredictable laws. In such an environment, every new form of leasing, or any atypical novel nuance, might lead not only to rejection of necessary permissions from the side of the agency but might allow also for escaping the licensing and other regulatory requirements as well. For consumer lessees often this may be more detrimental than empowering the lessor to repossess quickly, if necessary even ex parte in court or extra-judicially.

\subsubsection{Dilemmas Corollary to the True Lease versus Security Leasing Classification}

The gist of this dichotomy stems from the fact that all legal system have known and have regulated lease or rent contracts, at least, from Roman times on. Although normally referred to as 'true lease' especially in US jurisprudence, they could be referred to also as 'classical' or 'paradigm' leases. All civil codes, for example, recognize the nominated contract of 'lease' or 'rent.' Faced with the newcomer contract 'leasing' - that has in English often been referred to simply as 'lease' - then the first issue for lawyers from civilian legal systems was whether the two are different

to a hire purchase agreement, used to be the very favourable tax treatment it received, in that the financier (the lessor) could claim capital allowance for the asset, some of which benefit could be passed on to the company (the lessee) and the lessee could deduct the hire payments as revenue expenses." After the 2006 Act, however, this has changed with respect to long-term finance leases ('long-funded leases' in the statute) and "such leases are now taxed according to their economic substance, in a way very similar to loans." Quoted from Gullifer, L., Payne, J., 2011, p. 41.

96 Gilmore, G., 1965, \$3.7, p. 81.

97 As Gilmore phrased it, "[...]'leasing' was sometimes said to make the lessee's balance sheet, under the beautifying effect of 'approved accounting methods' immensely more attractive to investors and to guarantee considerable tax advantages. The balance sheet nonsense, it may be thought, would hardly serve to delude the most uninformed widow or orphan, and the tax advantages could only be guaranteed good until the next revision of the tax regulations, if that long." Gilmore 1965, $\$ 3.7$, page 81 . 
or identical? Although the answer today is normally that the two are distinct categories of law, some dilemmas remain. Indeed, in some CEE systems the 'true' lease provisions of private law still apply mutatis mutandis to some classes of leasing transactions. In Hungary, as already mentioned, operating lease is simply taken to be equal with true or classical lease and consequently it escapes the duty of registration.

Whether this approach is adequate remains debatable for a variety of reasons. One of the considerations that is often superfluously skipped relates to the difference between 'contract' and 'transaction.' Namely, proper understanding of 'leasing' presumes comprehending also the difference that exists between 'lease' or rent contracts and leasing transactions. The difference admittedly is less visible in case of operating leasing as a two-party transaction, where the relations of the parties often may, indeed, be regulated by a single contract named as 'leasing;' notwithstanding that elements of other contracts may as well be hidden in it. However, operating leasing transactions may, indeed, be more than mere contracts, or based on a single relatively simple contract.

Yet the difference is more visible in case of the three-party financial leasing transaction, which not only includes more parties (not only the lessor and lessee) but is based on and made of much more than a single contract named as 'leasing. ${ }^{98}$ Financial leasing is a typical hybrid or rather synergic contract where the constituent contracts produce results different from any one of them individually. It is not without reason that the US UCC deals with transactions rather than with mere contracts.

Further, for civil law lawyers accustomed to distinguishing contracts based on the so-called major elements of contracts ${ }^{99}$ - which are actually based on criteria the origins of which often are unclear or at least it is not clear why this or that criterion has been selected as the dominating one this may result also in a fundamentally distorted picture on the essence of

98 As a positive example see, for example, Vasiljević who noted that "the leasing transaction should be differentiated from the leasing contract." He used the term 'construction' ("konstrukcija") instead of transaction. The pertaining text in Serbian language reads: "kod ove ustanove treba razlikovati celovitu lizing konstrukciju i lizing ugovor." Vasiljević, M., 1995, p 677.

99 Vasiljević stated that the so-called major elements of leasing contract are, on the one hand, the specification of the leasing object and, on the other hand, the fixing of the price to be paid by lessee. Id, page 677. To start with, for all the Unitary Systems it is the retained title (ownership), or the fact that each of the title finance transactions are also security agreements in economy equal with pledge or mortgage transactions, is that comes to the forefront. Additionally, as we will see below on the discussions on repossession and hell and high water clauses, for the financial and other leasing industries it is rather the legally guaranteed right to quick repossession and the enforceability of hell and high water clauses that ranks high. 
leasing. The key prerequisite is, for example, for a proper comprehension of how financial leasing works is exactly not the isolation of a single pair of 'major features' or 'major obligations' but rather understanding what the role of the synergic effects of a multitude of elements is in bringing about the desired results?

It is a related story that the selection of the 'major obligations' determines in civilian laws also where the newcomer 'leasing' is to be placed in the civil code (or in the Act on Obligations in the Western Balkan countries), or in the system of private law. This would then imply imposition of rules that may not necessarily fit the very nature of leasing and might constrict the development of the linked businesses. The ensuing discussion on the role hell or high water clauses mean for financial leasing in US might be the best example explaining the importance of the impact of these differences.

The true lease versus our central category - denominated herein simply as 'leasing' - generated, however, yet another important dilemma. Concretely: given that economically leasing is similar if not equal with loan transactions that are secured by a mortgage (registered pledge) on the object obtained with the loan, in the Unitary Systems that follow the functional approach enshrined into Article (Chapter) 9 of the US UCC, most of the retained title-based title finance transactions have been subjected to the registration, priority and enforcement rules of the same. Normally such leasing transactions are then for that reason referred to as 'security leases.' However, such treatment requires a formula for differentiating 'true' from 'security' leases.

On this specific point, the US solution does not seem to be the most practical one given that it leaves the decision to courts to decide that on a case-by-case basis. True, a formula made of a more or less agreed upon elements has developed based on a string of cases yet such an approach decreases predictability. It was not without reason that one US author aptly noted that although "[UCC] Article 9 provides for the optional filing [i.e., registration] of leases [but that] could easily be made mandatory, as it has been in at least Canadian province which has adopted Article 9 with this modification." 100

Indeed, the Canadian approach seems to be not only simpler and more practical but is as well (most presumably exactly for the same practical reasons) supported by significant portion of the affected stakeholders. ${ }^{101}$ Namely, the provinces subjected all leases (irrespective whether a

100 King, Kuenzel, Stone and Knight, Jr., 1997, Commercial Transactions under the Uniform Commercial Code and other Laws, Matthew Bender, \$21.02, p. 1221.

101 In the province of Ontario, for example, it was determined based on a questionnaire that $70.4 \%$ of the respondents supported the subjection of all long-term leases to the 
true or security lease) 'for a term more than one year' to registration; 102 this includes, for example, also leases automatically renewable for one or more terms totalling beyond one year. ${ }^{103}$ For the time being it is not clear whether the differentiation of true versus operating leases has caused problems in Croatia, where only the latter is subject to registration. It is not clear either whether such problems of differentiation exist in other jurisdictions of the region as well. The lack of empirical evidences, however, should not automatically lead to the conclusion that therefore these problems do not exist.

\subsection{DILEMMAS CONCERNING REPOSSESSION: OR WHY IS QUICK PROTECTION OF LESSORS' RIGHTS CRUCIAL?}

Presumably the most pressing problem of leasing industries on the Balkans and in much of Continental Europe since the very beginning of their operations have been the problems with repossession (or return) of the object of leasing. ${ }^{104}$ This notwithstanding that a provision containing a retained title (ownership) could be claimed to have been routinely included into leasing contracts and thus in principle the lessor - as owner - should have been in the position to protect its ownership in particular by regaining possession quickly. The lessors in reality, however, are hardly in the position to promptly react and take possession out of the hands of the lessee upon default if they would like to strictly follow the mandates of the law. Or, at least, they cannot do that out-of-court, what normally

registration, priority and conflicts of requirements of the secured transactions (in Canada: personal property security) laws. Moreover, as the survey revealed, $54.0 \%$ of the respondents always, and $28.7 \%$ often registered their leases in the personal property security register notwithstanding that that was not a legal obligation. Ziegel, J. S., Geva, G., Cuming, R. C. C., 1995, Commercial and Consumer Transactions - Cases, Text and Materials, $3^{\text {rd }}$ ed., Canada, Toronto, Emond Montgomery Publications, p. 64, referring to Ziegel and Denomme, 1992, How Ontario Lawyers View the Personal Property Security Act: An Empirical Survey, 20 Canadian Business Law Journal 90, pp. 102-4.

102 For Ontario see the definition of 'debtor' in section 1(1) on definitions and interpretation in the Personal Property Security Act, R.S.O. 1990, Chapter P. 10, last amended: 2017, c. 20, Sched. 9, s. 8-12, (https://www.ontario.ca/laws/statute/90p10, 19 January 2018).

103 Del Luca, Reilly, Smith and Winship, 2011, Secured Transactions under the Uniform Commercial Code and International Commerce, $2^{\text {nd }}$ ed., LexisNexis, p. 63.

104 It was not without a reason that Leaseurope stressed already in the introductory pages of its publication that "Unfortunately, the lessor's ownership of the lease asset, which is clearly crucial to any lease contract, is too often ignored by legislators charged with regulating accounting, taxes and other aspects of leasing." Leaseurope and Andersen, A., 1992, Leasing in Europe, London, McGraw-Hill Book Co., p. x. 
leads then to protracted litigation and ample opportunities for the lessee to damage, hide or dispose of the asset contrary to the underlying leasing contract. A look at the US experiences, as the jurisdiction where leasing was born, would reveal that self-help (out-of-court) repossession is common in practice, especially if automobiles are at stake. ${ }^{105}$

More reasons should be pointed at to understand why that is so. First and foremost, there is a crucial difference between the approaches of civil law and Anglo-Saxon systems. While the former do not tolerate self-help, or restrict out-of-court enforcement of rights heavily, the latter have never done that. Rather, they have always looked upon self-help as an important building block of commercial law. As the doyen of English commercial law, Roy Goode put it, the 'encouragement of self-help' is one of "the eight principles which together make up the philosophy of commercial law." 106 The position of civil laws is exactly the opposite and as a result prompt extra-judicial repossession of the collateral, or the object of leasing, is normally legally not possible. ${ }^{107}$ Or, the law is unclear on that crucial point. The lawmakers at any event are normally unwilling to explicitly introduce and regulate the details of how out-of-court enforcement could be exercised.

The position of common laws is superbly expressed in the domain of secured transactions law, which - as we already stressed more times includes also conditional sales and leasing transactions. The contrast in the fundamentals is sharp to the level of irreconcilability. Again, it was Grant Gilmore, a US scholar little known in Europe, who most succinctly expressed the quintessence of the American position that is to certain extent followed by many other common laws as well. As he put it, the enforcement part of UCC Article 9 "proceeds on the theory that the normal procedure after default is for the secured party to take possession of the collateral (if he does not hold it in pledge) and to dispose of it at a public or private sale, thereby creating a surplus (which must be returned to the debtor) or establishing a deficiency." 108 [Emphasis added.]

105 White and Summers, 2010, Uniform Commercial Code, $6^{\text {th }}$ ed., West, $\$ 26-7$, p. 1335.

106 Goode, 1988, The Codification of Commercial Law, Monash University Law Review, vol. 14, September pp. 136-153, page 148 . The other principles are: $1 /$ party autonomy, 2/ predictability, $3 /$ flexibility, 4/ good faith, 5/ the facilitation of security interests, $6 /$ the protection of vested rights, $7 /$ the protection of innocent third parties and the already mentioned 8 / encouragement of self-help.

107 On the various theories on protection of possession see Vodinelić, V. V., Čemu posesorni postupak? - O razlogu posesorne zaštite državine, Pravni zapisi, vol. V, no. 1 (2014), pp. 5-65.

108 Gilmore, G., 1965, \$43.1, p. 1183. 
In other words, it is generally recognized that it is crucial for the secured creditor (including the lessor) to have the right to repossess instantaneously upon default ${ }^{109}$ because that changes the strategic position of the parties: the lessee is prevented from damaging, hiding or disposing with the leasing object, it cannot use it anymore to generate income and the lessor can actually immediately sell it to mitigate its losses. Further, after repossession it is not the secured creditor who has to file a claim and bear the risks and costs of litigation aimed at proving that the lessee has breached the contract and therefore lessor is entitled to get back the asset, but it is the lessee who is to sue and bear all the costs and risks of a suit that will try to prove that the lessor had no right to repossess or it repossessed by breaching the rules. Disposal of the repossessed collateral (including object of leasing) could also be done extra judicially in the US; ${ }^{110}$ what may not be the case elsewhere.

Yet the story does not end with self-help repossession in the US because the system tries to help the secured creditor and the lessor also by making all possible avenues available. In Gilmore's words, UCC opted "for a loosely organized, informal, anything-goes type of foreclosure pattern, subject to ultimate judicial supervision and control which is explicitly provided for." 111 The lessor (secured creditor) may resort to the self-help avenue but it may shift to court enforcement at any time. The remedies, in other words, are said to be cumulative. ${ }^{112}$

What is of importance here is that nothing in the socio-economic or legal environment of post-socialist states makes the lessees, or debtors in these systems any different from their kin in the US. The risk of abuses by the lessee having possession of the object of leasing subject to a retained title are as real as in the US. Consequently, the cry of local leasing industries for changes should merit more understanding than that used to be the case until recent times. The privatization of bailiff systems in some of the countries and the acceleration of enforcement proceedings through

109 UCC section 9-609 according to which the secured party may take possession either "pursuant to judicial process or without judicial process [in which case, however, self-help repossession must satisfy the standard of] without breach of the peace." The secured creditor may, as per sub-section (c) of the same section, "require the debtor to assemble the collateral and make it available to the secured party at a place to be designated by the secured party which is reasonably convenient to both parties."

110 As White and Summers aptly put it: "The critical provisions in Part 6 [i.e., the enforcement Part] give the secured party the right to take possession of the collateral upon the debtor's default and to dispose of it in satisfaction of its claim, all without setting foot in court in most cases." [Emphasis added.] White and Summers, 2010, Uniform Commercial Code, $6^{\text {th }}$ ed., West, $\$ 26-2$, p. 1325.

111 Gilmore, G., 1965, Id.

112 UCC section 9-601(c) (Revised Version 1999). 
the involvement of public notaries ${ }^{113}$ are steps in the right direction yet may not be sufficient to boost, for example, equipment leasing, or generally local leasing industries.

Admittedly, abuses and overreaches from the side of secured creditors and lessors are also to be reckoned with. Hence, it would be desirable also to investigate whether proper counterbalances aimed at protecting consumer-lessees, or even lessees which are small scale businesses, could be introduced. It is little known yet in fact the US system possesses more layers of protections of the debtor (lessee) starting from the federal and State (mini) Fair Debt Collection Practices Acts, through the 'without breach of the peace' 114 and the 'commercial reasonability' standards, availability of punitive damages and other explicit rules sanctioning noncompliance, ${ }^{115}$ the limitations inherent to the $60 \%$ per cent rule, ${ }^{116}$ the tort of conversion, ${ }^{117}$ and the protections afforded to debtors through a string of constitutional cases testing the compatibility of self-help and ex parte measures through the lenses of the due process clause in the $14^{\text {th }}$ Amendment. ${ }^{118}$

What the above thoughts aim to highlight is that the importance of tools whereby the lessor's retained ownership could be promptly protected and why would it be important to allow for shift of the tactical position of the parties through repossession are not topics that should so easily be

113 For Serbia see, e.g., Milošević, M., 2016, Prinudno izvršenje na osnovu javnobeležničke izvršne isprave, Pravni zapisi, vol. VII, no. 2, pp. 271-296.

114 This standard was intentionally left open ended. Accordingly old cases are still of relevance. The gist of the standard is, as put by White and Summers is that " $i i] n$ general, the creditor may not enter the debtor's home or garage without permission. The debtor's consent, freely given, legitimates any entry, conversely, the debtor's physical objection bars repossession even from a public street. This crude two-factor formula of creditor entry and debtor response must, of course, be refined by a consideration of third party response, the type of premises entered, and possible creditor deceit in procuring consent." White \& Summers, UCC (2010), \$26-7, pp. 1335-36.

115 UCC section 9-626, titled 'Remedies for Secured Party's Failure to Comply with Article.

116 As per the $60 \%$ rule, if the debtor (including a lessee, consignee, conditional buyer) has paid $60 \%$ of the leasing instalments or $60 \%$ of the loan, then the lessor (secured party) cannot keep the object of leasing (collateral) but must sell (dispose of) it. This is essentially a consumer-protection device. UCC s. 9-620(3).

117 Conversion may be both a tort and a crime. Black's Law Dictionary defines it as "The wrongful possession or disposition of another's property as if it were one's own; an act, or series of acts of willful interference, without lawful justification, with any chattel in a manner inconsistent with another's right, whereby that other person is deprived of the use and possession of the chattel.."

118 The US Supreme Court cases dealing with the topic started with Fuentes v. Shevin (407 U.S. 67, 92 S. Ct. 1983, 32 L. Ed. 2d 556) that was decided in 1972 and with Mitchell v. Grant (416 U.S. 600, 94 S. Ct. 1895, 40 L. Ed. 2d 406) from 1974. 
dodged; as it used to be so far. Undoubtedly the lack of self-help and the impotency of ex parte and provisional measures theoretically obtainable from courts were those factors that caused the most headaches to Hypo Alpe-Adria Bank as well. Would be helpful to have empirical evidences available from the Bank for these reasons.

\subsubsection{US versus German model leasing contracts}

To the length of a short passage it ought to be added that the analysis of various model security or title finance contracts offered by various laws do support the above. In particular, while Canadian or US template contracts routinely contain provisions on self-help repossession, it is next to impossible to find anything similar, for example, in German model contracts.

Stummel's collection of model contracts, ${ }^{119}$ for example, in lieu of self-help repossession offers the following for the lessor in a contract named in German as "Leasingvertrag." First, the lessor gets the right to terminate the contract with immediate effect if the lessee is late with more than two consecutive lease payments (instalments) or with a significant portion thereof, or if the object was used contrary to contractual terms and despite written warning (s. 7(1)). Second, after default, however, the lessor may only "pursue the sale of the asset" - without the right to repossess it first. (s. 7(2)). If the sales has proved to be unsuccessful, third, the lessor gets the entitlement to charge damages based on an expert opinion (s. 7(4)). A far cry from the right to repossess extra-judicially but, fourth, the lessor may charge default interest on overdue amounts at a higher rate (s. 3(2)).

As one could realize, these remedies available to the lessor - obviously to the extent the Stummel model contract could be taken as representative of prevailing German positions and practices - aim to introduce a kind of peaceful, cooperative type of enforcement, which does not even reckon with repossession as an inevitable step. The most liberal US selfhelp rules, as opposed to that, "only" order the repossession professional (called 'repoman') attempting to repossess to retreat facing violence or threat of violence - with the right to retry as many times as needed.

While it deserves special consideration that both, the German cooperative and the US self-help-based enforcement methods occur in high rule of law countries, it remains doubtful which of the models would be suitable on the Balkans. Due to the proximity of the wars, one should be

119 Stummel, D., 2003, Standardvertragsmuster - zum Handels- und Gesellschaftsrecht (Deutsch-English), München, Beck, contract No. 11, pp. 387-395. 
cautious with too easily opting for the American model. Yet it should be also obvious that the German cooperative type of enforcement presuming that lessees would in the overwhelming number of cases voluntarily return the object of leasing, or allow for its sale from their premises by the lessor, is unrealistic. This was otherwise one of the key lessons also of the above-discussed Potisje leasing cases.

\subsubsection{Civil law jurisdictions: the importance of ex parte provisional (interim) measures}

One could legitimately argue that even if extra-judicial enforcement of security rights, or of the rights of lessors, is not possible, civil laws offer various provisional and interim measures that could be issued by courts and that these could supplement the common law self-help remedies. In particular, if some of these could be issued ex parte; ${ }^{120}$ (if ex parte measures are available at all in a jurisdiction). ${ }^{121}$ Where these measures function efficiently, indeed, they may be partial, or even full substitutes of selfhep repossession.

Three problems plague the law of provisional and ex parte measures; a topic which otherwise obviously would require a separate paper, if not a book. Here, a brief commenting should be sufficient. First, although the civil enforcement laws of Continental European systems, including those of CEE countries, formally contain a section, or at least a handful of provisions, devoted to provisional measures, they often remain dead letters on paper. It is fair to claim that in the region it is often hard to obtain these measures because the rules may not be sufficiently clear and prescriptive, the judges are trained to stick to the four corners of laws and are hardly willing to depart from the letters of provisions and consequently are hesitant to award them as that would make their decisions targets of attacks on appellate level - negatively affecting their success rate and through that their salaries.

For the same reasons, second, the contents of these measures is limited to a very few types of measures that could realistically be awarded. Typically courts - being aware of the limits of the local bailiff systems - are hesitant to award unorthodox measures and measures the enforcement of which would require more than the announcement of the decision. The

120 As per Black's Dictionary (DeLuxe, $7^{\text {th }}$ ed., 1999), ex parte means "Done or made at the instance and for the benefit of one party only, and without notice to, or argument by, any person adversely interested."

121 Hungarian civil procedure law, for example, knows not ex parte provisional measures. 
last concern hints already to the third typical problem of CEE provisional measures laws. Namely, even if formally these measures could be obtained relatively easily in courts, they may not be efficiently enforced. Repossession of a lathe - that would have been needed in the Potisje cases sketched above - would presumably be a measure of that sort as opposed to a freezing order (injunction) to a bank where various accounts of the debtor (lessee) are kept.

These claims unfortunately hardly could be corroborated with hard data and appropriate statistics. Additionally, no formula has been so far invented for "measuring" the ease with which these measures could be obtained, or an index for comparing the efficiency of the enforcement of these measures in various countries. The only solid yet useful foothold here is that while all sources readily agree that the English freezing injunction (earlier called as the 'Mareva Injunction') is normally awarded ex parte ${ }^{122}$ and that it can be easily and promptly be obtained, no quality source seems claim that with respect to the Balkan jurisdictions or the post-socialist states.

\subsubsection{The Unintended Consequences of Imperfect Enforcement Laws: Legal versus Illegal Repossessions}

As lessors typically have no right but to repossess the object of leasing only at the price of lengthy court proceedings, or their rights are not clear, often such practices are resorted to by them that verge on the borderline of legality and illegality. One such questionable practice relates to motor vehicle leasing transactions. Namely, as reported by investigative journalists (rather than discussed by scholars), leasing companies often keep a spare key to leased cars or trucks. In case of default they are then used quite similarly to the practices of US repomen: the employee, or the employee of an external private company, follows the movement of the lessee and waits for the lessee to leave the vehicle at a public place (e.g., public parking lot), whereupon in the right moment drives it to a storage of the leasing company first opening the doors using the spare key. ${ }^{123}$ The answer to the question whether this is a right that lawfully belongs to the lessor who has kept its ownership in many jurisdictions of the region remains unclear up until today.

122 Hoyle, 2006, Freezing and Search Orders, 4th ed., London, Informa, para 4.7., p. 33.

123 See, e.g., Flere, P., Leasing in Slovenia - the Fastest Growing Financial Service Industry notwithstanding the Discrepancy between Theory and Practice, in: Messmann, S., Tajti, T., 2007, p, 376. 


\subsection{THE ELECTION OF REMEDIES DOCTRINE VERSUS ITS EUROPEAN EQUIVALENTS}

\subsubsection{The Election of Remedies Doctrine Defined and its Historic Role in Developing Leasing and Secured Transactions Laws}

Although the election of remedies doctrine ${ }^{124}$ fell into disrepute in the US, the country wherefrom leasing stems, it is rarely mentioned that it did play an important role in developing leasing and eventually US secured transactions law. It ought to be immediately noted that the doctrine has been of general application and has never been only a specificity of leasing or secured transactions law. It is based on the policy "to avoid $d u$ plication of relief." 125

In its most rudimentary form, well before the UCC was first published in 1952 making a security interest from all title financing transactions, it was heavily litigated in the context of conditional sales contracts because of its inflexibility. This stemmed from the fact that it required "the conditional seller to elect between suing for the debt and repossessing the goods." In other words, "if he sued for the debt he lost his right against the goods; if he repossessed the goods, he lost his claim to the debt and, consequently, to any deficiency judgement." 126

As one may suspect, the doctrine could not survive unscathed in such rigid form because almost always there is a discrepancy between the value of the repossessed object of leasing (collateral in US), the resale price obtainable and the actual amount of the debt plus any accompanying costs (repossession, litigation, safekeeping and resale costs). ${ }^{127}$ Yet it was useful to demonstrate at the price of enormous number of litigated cases that rigid formulas do not work. ${ }^{128}$ As a result, the enforcement system enshrined

124 As the Black's Law Dictionary puts it, the election of remedies doctrine requires a claimant "to [choose] between two or more concurrent but inconsistent remedies based on a single set of facts." As such it may also be exploited as an "affirmative defense barring a litigant from pursuing a remedy inconsistent with another remedy already pursued, when that other remedy has given the litigant an advantage over, or has damaged, the opposing party."

125 Dobbs and Roberts, 2017, Law of Remedies: Damages-Equity-Restitution, $3^{\text {rd }}$ ed., West, page 740 .

126 Gilmore, G., 1965, \$43.1, page 1182.

127 See, e.g., Neth, S., 1972, Repossession of Goods: Due Process for the Consumer: What's Due for the Creditor, Case Western Reserve Law Review, vol. 24, no. 1, pp. 7063, p. 59. Although the article focused on the consumer financing context, most of the points on the election of remedies doctrine apply to $\mathrm{B} 2 \mathrm{~B}$ contact mutatis mutandis.

128 The text of the third draft is attached to Burdick, Codifying the Law of Conditional Sales, Columbia Law Rev., vol. 18, no. 2 (February 1928), pages 103-122. As Gilmore 
into UCC Article 9 "opts for a loosely organized, informal, anything-goes type of foreclosure pattern [yet which is] subject to ultimate judicial supervision and control which is explicitly provided for." ${ }^{129}$ Moreover, heeding to the experiences from the past, UCC Article 9 does not impose the duty on the secured creditor (including lessors and conditional sellers) to do a public sale because in US experience "sales, conducted on the courthouse steps, invariably bring a low price." 130

\subsubsection{The European Equivalents}

No doctrine similar to the common law election of remedies seems to be part of the legal systems of the post-socialist jurisdictions within the purview of this article. Thus, at the time when the leasing arrived to the Balkans hardly were there sufficiently solidified guidelines for the courts deciding the cases. Consequently it may validly be presumed that considerable differences existed in the understanding of judges deciding the first leasing cases on the remedies available to the lessor. The system, in the lack of specific rules on the rights of the parties to leasing contracts and of a doctrine similar to the election of remedies made the outcome of cases tainted with a varying degree of unpredictability. In the Potisje cases discussed above, although the judges were somewhat concerned with the equality of considerations given by the parties, they seems to have heeded more to the language of the underlying contracts and saw no problem in awarding both return of the object of leasing (obviously depreciated to certain degree) and payment of either damages or the remainder of instalments. ${ }^{131}$

described, the UCSA "dealt with the seller's rights on default in great detail [and] established an exceedingly rigid sequence of steps to be followed in repossession and disposition of the goods. In [States that enacted their own versions of Conditional Sales Acts based on the UCSA, courts were] more concerned whether the seller's procedures exactly complied with the statutory requirements than with standards of reasonable behaviour and fair play." Gilmore, G., 1965, \$43.1, pp. 1182-83.

129 Gilmore, G., 1965, §43.1, p. 1183.

130 White and Summers, 2010, Uniform Commercial Code, $6^{\text {th }}$ ed., West, \$26-1, p. 1325.

131 In a case decided by the Supreme Court of Serbia in 1997 (i.e., before the first act on leasing - the 2003 Law on Financial Leasing was enacted) the court stated that utilization (exploitation) of the object of leasing and the transfer of possession on the object of leasing as a precondition for that are the key features of leasing contracts and that the agreed upon sales option clauses can be invoked solely after the leasing agreement has been properly fulfilled. Based on this the court rejected the application of the provisions from the Act on Obligations that allow for division of obligations that otherwise the lessee asked for claiming that - similarly to one of the Potisje cases mentioned above - that the instalments paid by him covered the price of one of the two machines delivered to him based on the leasing contract. See Doklestić, 
This state of the law has hardly been satisfactorily resolved later when some of the high courts - faced for the very first time with the question of what the legal nature of the newcomer leasing contracts was - decided that the provisions of one of the nominated contracts should apply. A decision of the High Court of Croatia from 2002, for example, stated that the rules on instalment sales should apply to leasing contracts. ${ }^{132}$ Notwithstanding that reference to sales law was made by the court, the lessee was ordered both to return the object of leasing and to pay a rent until the termination of the contract.

Not a Balkan country, but a 1991 Hungarian Supreme Court judgment might corroborate this point as well. The decision stems also from the era of non-regulated leasing. The court found that not only the elements of instalment sales but also of (classical) lease are contained in the otherwise atypical leasing contract. This qualification was detrimental for the lessee because it prevented him from relying on the statute of limitations that would have been available had the court applied the rules on classical lease vis-à-vis the instalments. Consequently, it had to pay both the leasing fee and late payment interest. ${ }^{133}$

In general, one may be tempted to presume that the leasing laws enacted in the later phase of leasing's presence in the region have struck a better balance as far as the remedies of the parties are concerned given that these normally devote substantial detail to the rights of the parties to leasing contracts. Indeed, many of these laws seems to be preoccupied with listing in great detail the rights of the parties. Whether these remain sensibly flexible or rather unwittingly and gradually with each new amendment of the laws make a further step towards becoming as rigid as the American laws in the pre-UCC phase, would deserve a separate analysis. As hardly are lawmakers taking a look at such old laws as the US election of remedies doctrine, otherwise dodged by scholars of the source country as well, there is a danger that it is not sufficiently understood that rigid formalism seems not to be the path to be stepped on. Linking these points to our observations: while repossession or prompt "return" of the

S., Víg, Z., Enforcement of Contracts in Serbia, in: Messmann, S., Tajti, T., 2009, The Case Law of Central and Eastern Europe - Enforcement of Contracts, Germany, Bochum, European University Press, p. 913.

132 Visoki trgovački sud Republike Hrvatske, Pž-555/00 as of $26^{\text {th }}$ of February 2002. No. 7/013 in the Collection of Croatian Commercial Courts ("Zbirka rješidbi Hrvatskih trgovačkih sudova").

133 Hungarian Supreme court decision No. BH 1991.357. For a brief synopsis of the case see Hete, N., Leasing in Hungary - A Burgeoning Business amidst of a Non-Regulated Legal Environment, in: Messmann, S., Tajti, T., 2007, pp. 234-35. 
object of leasing if disregarded, the attention is devoted to details that may be of lesser importance in practice.

The bigger issue is that in most cases it has, neither has been properly discussed and understood, nor has a consensus on the policy choices concerning remedies been reached. Rather, the leasing laws in the region seem to develop quite hectically and are shaped often under the influence of temporary factors, often more dominated by academic considerations than practical needs of the industry. Moreover, the discussions related to the rights of the parties upon default normally look upon repossession as a side rather than a central issue, if at all.

\subsection{WHAT CAN LAW DO TO CREATE A MORE LEASING-SUPPORTIVE LEGAL ENVIRONMENT}

\subsubsection{The Importance of 'Hell or High Water Clauses' and the Underlying Policies}

Separate paper could be devoted to the question how law could further boost the development of leasing industries - in particular equipment leasing - in the region. Besides the above discussed points, in the region little (if any) attention is devoted to the role the so-called 'hell or high water clauses' play in the context equipment and financial leasing. The best indirect evidence of their important role is the high esteem they enjoy in the eyes of courts in the US. That this topic escaped the attention not only of lawmakers of the region but also of scholars could indirectly be illustrated by the lack of scholarly and industrial papers that would analyse the topic in depth.

The hell or water clause, as defined by the Black's Law Dictionary is "a clause in a personal-property laws requiring the lessee to continue to make full rent payments to the lessor even if the thing leased is unsuitable, defective, or destroyed." 134 In the US, these clauses play a key role for financial leasing transactions because - in the context of these tri-partite transactions - they allow financiers to isolate themselves from the defects of the object of leasing the acquisition of which they otherwise finance. They prevent the lessee from refusing payment of instalments to the financier by invoking warranty claims (i.e., claims that the object of leasing is defective, unsuitable or destroyed), what would otherwise be a relatively easily exploitable objection and tactical tool in the hands of lessees facing financial difficulties.

134 Garner, B. A., (editor in chief), 1999, Black's Law Dictionary, DeLuxe, $7^{\text {th }}$ ed. 
The main economic benefit of properly working hell or high water clauses is that banks and other financial organizations that are interested in profiting from lending money but do not want to be entangled in warranty disputes - may appear on the equipment leasing market. More participants competing on the same market reasonably would result then in more favourable interest rates and better terms and conditions for lessees as well. Eventually the pricy leasing that could not be afforded by small and mid-scale start-ups might very shortly be replaced by affordable ones upon the entry of such new financiers on the leasing market.

At present time it is next to impossible to learn whether such clauses are used in this niche of Europe at all and whether they are enforceable unreservedly. This notwithstanding that financial leasing as such has been recognized by most of the post-socialist legal systems of Europe.

\subsubsection{The Role a Supportive Court System may Play}

The hell or high water clauses are worthless, however, without the full support of courts. The real question, however, is not only whether these clauses would a priori be declared null and void, or only if some specific further terms and conditions have been adhered to as well, but whether in a given jurisdiction lessees could easily force the financier into protracted litigation by invoking warranty claims related to the object of leasing?

One of the leading US cases on this issue - In Re O.P.M. Leasing Services $^{135}$ - might be very instructive in this respect. Notwithstanding that the case involved more participants than three and the fact pattern is as well quite complex, it were the traditional participants of financial leasing transactions that played the central role. The dispute concerned exactly the enforceability of hell or high water clauses: the lessee (West Virginia) refused to continue paying the instalments (lease payments) to the financier (LaSalle) because the computer equipment leased from the lessor (OPM) was not properly maintained. The Master Lease agreement contained a properly drafted hell or high water clause. ${ }^{136}$

What might be unusual to lawyers from the Balkans is the unconditional support and recognition the court deciding the case gave to the

135 In Re O.P.M. Leasing Services, United States Bankruptcy Court, Southern District of New York, 21 B.R. 993 (1982).

136 The clause (Section 5.3.(iii) of the Master Lease between OPM and West Virginia, or lessor and lessee) read: "[l]essee's obligation to pay directly to such assignee [i.e., the financier, LaSalle] the amounts due from lessee under any Equipment Schedule ... shall be absolutely unconditional and shall be payable whether or not any Equipment Schedule is terminated by operation of law, any act of the parties or otherwise." [Emphasis added.] 
industry and to the clause. The force in the language of the reasoning deserve citing here. The court, first, noted that these clauses "must be given full force and effect as a matter of law" because it was the intention of all parties involved to be bound by such a clause. Hence, "[t]o deny this clause its full force and effect would effectively reconstruct the contract contrary to the intent of the parties, which reconstruction would be impermissible."

More important was, however, secondly, the court's willingness to heed the role these clauses play for the equipment leasing industry. As it put it "[t]he essential practical consideration [is] [...] that these clauses are essential to the equipment leasing industry. To deny their effect as a matter of law would seriously chill business in this industry because it is by means of these clauses that a prospective financier-assignee of rental payments is guaranteed meaningful security for his outright loan to the lessor. Without giving full effect to such clauses, if the equipment were to malfunction, the only security for this [financier-assignee] would be to repossess equipment with substantially diminished value." [Emphasis added.]

If we add to this that in most countries of the Western Balkans and CEE post-socialist countries quick repossession of the object of leasing is impossible but at the price of protracted litigation potentially lasting not only for months but even for years, the 'substantially diminished value' argument would practically and normally result in even more substantially depreciated value by the time the lessor is given the possession on the object of leasing back.

It is not clear what the fate of hell or high water clauses might be in the regions' courts at the time being. It is not clear either whether the Hypo Bank had tried to rely on them at all. It may, however, be legitimately speculated that the failure to use these clauses, or the problems with the enforceability of such clauses (if they were used by the Hypo Bank at all), might have been another reason behind the emergence of problematic leasing transactions on the books of Bank.

\section{Further Topics to Explore}

The above analysis is far from being complete. The confines of this paper, however, do not allow for their coverage. In their case the lack of court cases, scholarly or industrial in-depth analyses, as well as the scarcity of empirical evidences are even more exacerbating factors that should be reckoned with. This applies especially to the exploration of the consumer-protection aspects of leasing ${ }^{137}$ given the appearance of such giant

137 For a detailed comparative analysis see Stănescu, C. G., 2015, Self-Help, Private Debt Collection and the Concomitant Risks, Springer. 
private debt collection companies in the region as EOS Group ${ }^{138}$ or Intrum Justitia, ${ }^{139}$ in addition to the smaller local ones.

At least two broader topics should, however, be briefly commented upon here. The first relates to the treatment of leasing in bankruptcy (insolvency) proceedings. Namely, although the pertaining bankruptcy law provisions may seem to be clear, it is not documented whether they work in practice as smoothly as expected. Similarly to German or Austrian law, the Western Balkan countries' bankruptcy laws also foresee that retained ownership allows for the separation of the asset (i.e., object of leasing) and not only for separate satisfaction (payment) in priority to other creditors. ${ }^{140}$ What remains empirically untested is whether these provisions are enforced exactly as foreseen by the laws? If yes, then with what frequency? In particular, what happens to assets - like the lathes mentioned above in the context of the Potisje leasing case study - where the components of more manufacturers are mounted onto the machines and the lathe remains unfinished and cannot be sold as an end fully-finalized product?

The second issue concerns the potential impact of the rule of law on the implementation of leasing laws as well as generally on the activities of leasing companies. The issue is not only the efficiency of courts, the bailiff systems or the agencies overseeing the leasing market but also the impact the embeddedness of law ${ }^{141}$ in consumers and business people may have on the enforcement of leasing contracts. This is a legitimate question because, for example, one may suppose that in a high rule of law country there may not be a need for out-of-court repossession or similar extra-judicial tools

138 The Hamburg-based international corporation is already present in most of the Western Balkan countries, (https://www.eos-solutions.com/company/locations-worldwide/).

139 For details, including the countries of operation, see https://www.intrum.com/en/ services/.

140 The Serbian Insolvency Act of 2009 regulates the treatment of financial leasing in section 90. See also Stojanović, M., Lalović Maric, N., Chapter on Serbia, in: Hoening, C., Hammerl, C., 2014, Insolvency and Restructuring in Central \& Eastern Europe, pp. 393-426 Vienna, Linde, section 8.7.3., at page 412. For Croatian law see Grubešić, A., Valinčić, D., and Tadić-Čolić, L., Chapter on Croatia, Id., pp. 165-200, section 8.4.4., at page 181 .

141 Krygier posited 'social embeddedness and significance of law' as one of the prerequisites of the rule of law besides requirements on the $1 /$ scope of law ('equality before the law'); 2 / character of the law ("people will be able to be guided by it"); and 3/ the integrity of legal institutions. As per this criterion "[t]he law must be, and must be widely expected and assumed to be, appropriate and to matter, to count, in the exercise of social power, both by those who exercise it (which should be far more than just officials) and by those on whom it is exercised." Krygier, M., 2001, Transitional Questions about the Rule of Law: Why, What, and How?, in: East Central Europe, Special Issue, vol. 28, part 1, pp. 1-35 (Quoted from pp. 9-12). 
that the US system takes as crucial for the proper functioning of the leasing market. This because the overwhelming part of lessees would voluntarily retransfer (return) the object of leasing or would otherwise amicably settle any disputes with the lessors.

Perusing the above mentioned Stummel German model leasing contract, ${ }^{142}$ therefore the real practical question is whether this contract transplanted to Western Balkans countries would work appropriately without any modifications given the lower level of the rule of law compared to Germany or Austria? Not only because of the experiences with the above sketched leasing cases from Vojvodina but generally whoever knows the Western Balkans would agree that the answer presumably would be in the negative. This may also cast a closer light on what might have gone wrong with the leasing project of the Hypo Bank notwithstanding that German and Austrian leasing laws are not identical.

\section{Concluding Thoughts and Recommendations}

Although the hybrid contract and transaction invariably known in the region as 'leasing' has made a remarkably successful entry into the Western Balkans, the related scholarship is very limited. Analyses that would not only critically assess the problems encountered during this process based on empirical evidences are largely lacking. This paper aimed to fill this gap in the hope of better understanding the local versions of leasing as well as the local leasing markets, possibly by shedding light on the reasons that had generated the problematic leasing portfolios of the Hypo Bank while operating in this niche of Europe.

The undoubtedly unorthodox pages devoted to the first generation of local experimentations with the introduction of leasing from Vojvodina, as a kind of semi-empirical evidences, should not be cherished only as modest contributions to legal history. They should be valuable also for, at least, three more reasons. First, as it is not known what concrete reasons are due the problematic leasing portfolios of the Hypo-Alpe-Adria Bank, it may be presumed that the hurdles the lessor from Vojvodina faced were essentially identical or substantially similar with those faced by the Bank a few years later when encroaching the Western Balkans.

Secondly, these cases may provide those interested in entrepreneurship, start-ups and legal engineering with good insight into the business environment of those days, showing that entrepreneurship, openness to new business ideas as well as legal innovation has not been unknown in

142 See section 3.2.1. above. 
this part of Europe either. Moreover, the judges deciding the leasing cases displayed as well not only proper understanding of many features of the newcomer leasing transaction but felt it important to set such a balance between the parties that would not kill the new business model either.

Thirdly, the cases and the related anecdotal evidence of the author clearly confirm that the key problem leasing companies faced and continue to face today is the lack of legal tools whereby they could promptly repossess the object of leasing out-of-court, or at least via courts. Such possibilities are either not recognized by local laws, or what the legal system offers are only inappropriate substitutes. Often, however, the law is not clear on the repossession-related rights of lessors. The surviving dilemmas about the definitions, what types of leasing to regulate, subject to registration and other requirements, are further problems that cannot be disregarded either.

Yet if the ultimate question is how to boost the local leasing industries and markets - in particular the heavily underdeveloped equipment leasing segments -, besides the proper tackling of the dilemmas identified and commented upon above, special attention should be given to two considerations. The first concerns the trend of treating leasing as a security contract akin to pledges or in US vocabulary treating it as a 'secured transaction.' Here, it should be realized that such an approach is characteristic not only of the US and some major common law systems: the Unitary Model was taken over namely also by the drafters of the European soft law instrument - the Draft Common Frame of Reference ${ }^{143}$ - and more recently by some African countries as well. ${ }^{144}$ Though one should also add to the list the sui generis solutions of German law, which also looks upon leasing as a form of secured transaction. The key benefits of this approach are that being subject to the same set of rules would not only make the system more predictable but would make bypassing either the leasing or the security laws hard.

The second consideration that seems to have been almost completely bypassed so far relates the complex of issues surrounding the above-

143 See, e.g., Tajti, T., 2013, Systemic and Topic Mapping of the Relationship of the Draft Common Frame of Reference and Arbitration, Lithuanian, Vilnius, Kazimieras Simonavičius University.

144 The draft Ethiopian secured transactions law has been circulate in December 2017. The proposal was inspired by the US Unitary Model. See Asress Adimi Gikay, 2017, Rethinking Ethiopian Secured Transactions Law through Comparative Perspective: Lessons from the Uniform Commercial Code of the United States, Mizan Law Review, vol. 11, no. 1, pp. 153-197, (http://www.SSRN.com). See also Iheme, C. W., 2016, Towards Reforming the Legal Framework for Secured Transactions in Nigeria, Springer. 
sketched 'hell or high-water clauses', the full recognition of which by courts is so crucial for the development of leasing industries. The key benefit of recognition of these clauses is not only that instead of channelling a significant portion of leasing disputes to years-lasting litigations on whether the object of leasing was defective in any respect, full support and unreserved enforceability of these clauses in courts would not only make more financiers willing to join the financial leasing market but would also make the concomitant transaction costs decreased in the long run.

The ultimate lesson from all the above, however, is that there is still a lot to do until all the inherent strengths of leasing will be readily exploitable in the Western Balkans. If that happens, contrary to the fears, that will be for the benefit not only of the leasing industries, but also for all on the recipient side; from SMEs through consumers appearing in the shoes of lessees. The ultimate winners, however, would be the economies of the Western Balkan states, which for that reason should revisit and pay closer attention to their leasing laws.

\section{BIBLIOGRAPHY}

\section{A. PRIMARY SOURCES OF LAW: STATUTORY AND REGULATORY LAW:}

\section{Albania:}

Law No 9396 of 12 May 2005 on Financial Leasing

\section{Bosnia and Herzegovina:}

Zakon o lizingu, Službene novine Federacije BiH, br. 85/08, 39/00, 65/13 i 104/16

\section{Croatia:}

Zakon o leasingu (2013)

\section{Hungary:}

Hungarian Civil Code of 2013 (Full title: Law No. V. of year 2013 on the Civil Code in Hungarian: “A Polgári Törvénykönyvről szóló 2013. évi V. törvény")

\section{Poland:}

Civil Code, Book Three on Obligations, Title XVIII on Contract of Leasing

\section{Serbia:}

Zakon o finansijskom lizingu (2003 as amended) 


\section{Ukraine:}

The Law of Ukraine “On Financial Leasing” (14 Jan. 1999 N 394-XIV as amended)

\section{Former Yugoslavia:}

Zakon o preduzećima 1989 (Enterprise Act 1989)

Zakon o obligacionim odnosima 1978 [Act on Obligations 1978] (as amended by the various successor States of the former Yugoslavia)

\section{COURT DECISIONS:}

\section{Croatia:}

Visoki trgovački sud Republike Hrvatske, Pž-555/00 as of $26^{\text {th }}$ of Febr. 2002

\section{United States:}

In Re O.P.M. Leasing Services, United States Bankruptcy Court, Southern District of New York, 21 B.R. 993 (1982)

Fuentes v. Shevin (407 U.S. 67, 92 S. Ct. 1983, 32 L. Ed. 2d 556) [1972]

Mitchell v. Grant (416 U.S. 600, 94 S. Ct. 1895, 40 L. Ed. 2d 406) [1974]

\section{SOFT LAW:}

\section{European Union:}

EU Commission Press Release, State Aid: Commission Approves Plan to Orderly Wind Down Hypo Group Alpe Adria, 3 Sept. 2013

\section{United States of America:}

Uniform Commercial Code (Revised Version 1999)

\section{B. SECONDARY SOURCES OF LAW: BOOKS, MONOGRAPHS AND COMMENTARIES:}

1. Allcock, B. J., 2000, Explaining Yugoslavia, London, Hurst \& Co.

2. Altman, I. E., Hotchkiss, E., 2006, Corporate Financial Distress and Bankruptcy: Predicts and Avoid Bankruptcy, Analyze and Invest in Distressed Debt, $3^{\text {rd }}$ ed., Wiley \& Sons.

3. Bar, C. von, Clive, E. (eds.), 2010, Principles, Definitions and Model Rules of European Private Law - Draft Common Frame of Reference (DCFR), Oxford University Press.

4. Bork, R., Security Rights and Insolvency Law in the Germanic Legal Systems, in: McCormack, G. \& Bork, R. (eds.) 2017, Security Rights and the European Insolvency Regulation, Cambridge-Antwerp-Portland, Intersentia.

5. Carballo Fidalgo, M., Carballo Piñeiro, L., Mangano, R., Security Rights and Insolvency Law in the Roman Legal Systems, in: McCormack, G. \& Bork, R. (eds.) 
2017, Security Rights and the European Insolvency Regulation, Cambridge, Intersentia.

6. Dalhuisen, H. J., 2016, Dalhuisen on Transnational Comparative, Commercial, Financial and Trade Law, vol. III, $6^{\text {th }}$ ed., Hart.

7. Duggan, A. \& Brown, D., 2012, Australian Personal Property Securities Law, Australia, LexisNexis Butterworths.

8. Dobbs, B. D. and Caprice, L. R., 2017, Law of Remedies: Damages-Equity-Restitution, $3^{\text {rd }}$ ed., West.

9. Doklestić, S., Víg, Z., Enforcement of Contracts in Serbia, in: Messmann, S., Tajti, T., 2009, The Case Law of Central and Eastern Europe - Enforcement of Contracts, Germany, Bochum, European University Press.

10. Flere, P., Leasing in Slovenia - the Fastest Growing Financial Service Industry notwithstanding the Discrepancy between Theory and Practice, in: Messmann, S., Tajti, T., 2007, The Case Law of Central and Eastern Europe - Leasing, Piercing the Corporate Veil [...], Germany, Bochum, European University Press.

11. Harmathy, A., The EBRD Model Law and the Hungarian Law, in: Norton, J., J. Andenas, Mads, 1998, Emerging Financial Markets and Secured Transactions, UK, London, Kluwer.

12. Hete, N., Leasing in Hungary - A Burgeoning Business amidst of a Non-Regulated Legal Environment, in: Messmann, S., Tajti, T., 2007, Case Law of Central and Eastern Europe - Leasing, Piercing the Corporate Veil [...] (Germany, Bochum, European University Press.

13. Hoening, C., Hammerl, C., 2014, Insolvency and Restructuring in Central \& Eastern Europe, Vienna, Linde.

14. Iheme, C. W., 2016, Towards Reforming the Legal Framework for Secured Transactions in Nigeria, Springer.

15. Garner, B. A., (editor in chief), 1999, Black's Law Dictionary (DeLuxe, $7^{\text {th }}$ ed.).

16. Goode, R. M., Ziegel, S. J., 1965, Hire-Purchase and Conditional Sale - A Comparative Survey of Commonwealth and American law, UK, London, British Institute of Int'l and Comparative Law.

17. Gilmore, G., 1965, Security Interests in Personal Property, Boston-Toronto, Little, Brown and Co.

18. Gullifer, L., Payne, J., 2011, Corporate Finance Law - Principles and Policy, $1^{\text {st }}$ ed., Oxford and Portland, Hard Publishing.

19. Hoyle, M. S. W., 2006, Freezing and Search Orders, $4^{\text {th }}$ ed., London, Informa.

20. King, B. D., Kuenzel, C., Stone, B., Knight, Jr., W. H., 1997, Commercial Transactions under the Uniform Commercial Code and other Laws, Matthew Bender.

21. Lansferd, T., 2014, Political Handbook of the World 2014, Sage \& CQPress.

22. Leaseeurope and Andersen, A., 1992, Leasing in Europe, London, McGraw-Hill Book Co., Statement on Lease Accounting.

23. Luca, F. L. del, Reilly, T. M., Smith, E. E., Winship, P., 2011, Secured Transactions under the Uniform Commercial Code and International Commerce, $2^{\text {nd }}$ ed., LexisNexis.

24. McCormack, G. \& Bork, R., (eds.) 2017, Security Rights and the European Insolvency Regulation, Cambridge-Antwerp-Portland, Intersentia. 
25. McCormack, G., Security Rights and Insolvency Law in the Common Law System, in: McCormack, G. \& Bork, R., (eds.) 2017, Security Rights and the European Insolvency Regulation, Cambridge, Intersentia.

26. Messmann, S., Tajti, T., 2007, The Case Law of Central and Eastern Europe - Leasing, Piercing the Corporate Veil and the Liability of Managers \& Controlling Shareholders, Privatization, Takeovers and the Problems with Collateral Law, Germany, Bochum, European University Press.

27. Messmann, S., Tajti, T., 2009, The Case Law of Central and Eastern Europe - Enforcement of Contracts, Germany, Bochum, European University Press.

28. Müller, M., 2014, Bankensanierung statt Bankinsolvenz: Sanierungsablauf am Beispiel der Hypo Alpe-Adria Bank AG, Hamburg, Diplomica Verlag.

29. Norton, J. J., Andenas, M., 1998, Emerging Financial Markets and Secured Transactions, UK, London, Kluwer.

30. Stănescu, C. G., 2015, Self-Help, Private Debt Collection and the Concomitant Risks, Springer.

31. Stefoff, R., 2006, The Telephone, New York, Marshall Cavendish.

32. Stummel, D., 2003, Standardvertragsmuster - zum Handels- und Gesellschaftsrecht (Deutsch-English), München, Beck.

33. Tajti, T., 2013, Systemic and Topic Mapping of the Relationship of the Draft Common Frame of Reference and Arbitration, Lithuanian, Vilnius, Kazimieras Simonavičius University.

34. Tajti, T., Security Rights and Insolvency Law in the Central and Eastern European Systems, in: McCormack, G. \& Bork, R., (eds.) 2017, Security Rights and the European Insolvency Regulation, Cambridge-Antwerp-Portland, Intersentia.

35. UNCITRAL Legislative Guide on Secured Transactions (New York, 2010).

36. Vasiljević, M., 1995, Trgovinsko pravo, $4^{\text {th }}$ ed., Belgrade, Savremena administracija.

37. Vékás, L., (ed.), 2013, Commentary of the Civil Code ("A Polgári Törvénykönyv magyarázatokkal") $1^{\text {st }}$ ed., Budapest, Complex.

38. Vilus, J., Carić, S., Šogorov, S., 1984, Međunarodno privredno pravo, Belgrade, Naučna knjiga.

39. White, J. J., Summers, S. R., 2010, Uniform Commercial Code, $6^{\text {th }}$ ed., West.

40. Williams, M., Lu, H. and Ong, C. A., Secured Finance Law in China and Hong Kong, Cambridge, 2010.

41. Ziegel, S. J., Geva, B., Cuming, R. C. C., 1995, Commercial and Consumer Transactions - Cases, Text and Materials, $3^{\text {rd }}$ ed., Canada, Toronto, Emond Montgomery Publications.

\section{LAW REVIEW ARTICLES:}

1. Beširević, V., 1989, Odgovornost za privredne prestupe i prekršaje prema odredbaman Zakona o preduzećima, Savremena praksa, ISSN 0036-5173, vol. 24, no. 1296.

2. Burdick, M. F., 1928, Codifying the Law of Conditional Sales, Columbia Law Rev., vol. 18, no. 2 (Febr.).

3. Burack, L. M., 1969, American Private Direct Investment in Eastern Europe: Intersection of Business Interests and Foreign Policy, 21 Stanford Law Review 877 (April). 
4. Kalss, S., 2010, Measures by the Austrian Regulatory Authorities in Response to the Financial Market Crisis, European Business Organization Law Review, 11.

5. Krygier, M., 2001, Transitional Questions about the Rule of Law: Why, What, and How?, East Central Europe, Special Issue, vol. 28, part 1.

6. Milošević, M., 2016, Prinudno izvršenje na osnovu javnobeležničke izvršne isprave, Pravni zapisi, vol. VII, no. 2.

7. Neth, S., 1972, Repossession of Goods: Due Process for the Consumer: What's Due for the Creditor, Case Western Reserve Law Review, vol. 24, no. 1.

8. Stanford, M. J., 1987, Rapport explicatif sur le projet de convention sur le Creditbail international, Uniform Law Review, vol. 15, no. 11.

9. Tajti, T., 2002, Viehweg's Topics, Article 9 UCC, the "kautelarische Sicherheiten" and the Hungarian Secured Transactions Law Reform, Vindobona J. of Int'l Commercial Law and Arbitration, vol. 6, no. 1.

10. Tajti, T., 2011, Consignments and the Draft Common Frame of Reference, Pravni zapisi, vol. II, no. 2.

11. Tajti, T., 2015, Franchise and Contract Asymmetry: A Common Trans-Atlantic Agenda?, Loyola of Los Angeles Int'l \& Comparative Law Review, vol. 37, no. 1.

12. Vodinelić, V. V., 2014, Čemu posesorni postupak? - O razlogu posesorne zaštite državine, Pravni zapisi, vol. V, no. 1.

\section{WEEKLY AND DAILY NEWSPAPERS:}

1. Bryant, C., Finance Probes Stretch Limits of Justice System, Wall Street Journal, 22 Oct. 2010 issue, at 3 (special supplement on Austria).

2. Shotter, J., Austria Bad Bank Plan Risks Breaking Bloc's Budget Limit, in: Financial Times, 11 March 2014 issue.

\section{INTERNET-BASED SOURCES:}

1. Shields, M., Austria sells Hypo Balkans network to private equity firm Advent, Reuters (23 Dec. 2014),(http:// Austria sells Hypo Balkans network to private equity firm Advent Michael Shields).

2. Srdoc, N., Austria's Hypo Group Alpe Adria: Collapse of the Rule of Law in Europe's Largest Post-WWII Banking Scandal - Billions Missing, Culprits Still at Large, Huffington Post, 13 October 2017 issue, (https://www.huffingtonpost.com/ entry/hypo-group-alpe-adria-collapse-of-the-rule-of-law_us_59e06ab8e4b003f$928 \mathrm{~d} 5 \mathrm{e} 5 \mathrm{c} 6)$.

\section{INDUSTRY PUBLICATIONS:}

1. EIB, Assessment of Financing Needs of SMEs in the Western Balkan Countries - Synthesis Report (August 2016), (http://vienna-initiative.com/wp-content/ uploads/2016/09/EIB_assessment_of_financing_needs_of_smes_in_the_western_balkans_synthesis_en_compressed.pdf).

2. ELFA, 2017 Survey of Equipment Financing Activity of the US Equipment Leasing and Finance Association (ELFA), (https://www.leasefoundation.org/wp-content/uploads/2017/07/2017sefaexecutivesummary.pdf).

3. HETA Asset Resolution AG, Annual Financial Report 2015. 


\title{
LIZING U ZEMLJAMA ZAPADNOG BALKANA I BANKROT AUSTRIJSKE HIPO ALPE ADRIJA BANKE
}

\author{
Tibor Tajti (Thaythy)
}

\section{REZIME}

1. Izučavanje lizinga, kao jednog od najuspešnijih ugovora koji su dospeli u zemlje zapadnog Balkana iz Sjedinjenih Američkih Država posredstvom jednog od zapadnoevropskih pravnih sistema, zaostaje za značajem koji lizing ima, ili bi mogao da ima u ekonomijama ovih zemalja. $\mathrm{Na}$ primer, poslovi lizinga u ovom delu Evrope su veoma koncentrisani na putnička vozila i ostale tipove vozila, a lizing mašina, postrojenja i industrijske opreme je nerazvijen, što predstavlja problem jer je najveća prednost ovog oblika lizinga što je dostupan malim i srednjim firmama početnicama (start aps) koje nemaju šta da ponude bankama kao zalogu za kredit. Deo krivice za to se svakako može pripisati nedostacima pravne regulative i tome da lizing još uvek nije dovoljno proučen i shvaćen.

2. Članak pokušava da ispuni ovu prazninu i zbog toga što je peta po veličini banka Austrije Hipo Alpe Adrija banka, između ostalog, bankrotirala zbog problematičnih lizing poslova na zapadnom Balkanu. Ipak, cilj članka nije da se konkretni razlozi bankrotiranja Hipo banke razotkriju, jer to i nije moguće zbog nedostupnosti dokaza i materijala. Umesto toga, članak samo sugeriše da su ovi razlozi bili isti kao i oni koji se mogu identifikovati i danas oslanjajući se na uporedno pravo, doduše ne ograničavajući se samo na ta zapadnoevropska prava koja su tradicionalno služila kao modeli, nego uvidom i u pravo $\mathrm{SAD}$, kao izvorište modernog tipa lizinga, i u rešenja i probleme susednih i drugih postsocijalističkih država.

3. Pored komparativnog prava, za identifikovanje glavnih problema koji su postojali krajem osamdesetih i početkom devedesetih, članak ukratko prezentira i iskustva sa uvođenjem verzije lizinga od strane jedne vojvođanske firme u doba kada nije bilo nikakve specijalne regulative o lizingu. Slučaj dobro pokazuje da je krajem osamdesetih postojalo preduzetničkog duha, privatne inicijative i interesa za uvođenjem metoda poslovanja i pravnih solucija testiranih na zapadu. Presude donete u ovim predmetima dobro pokazuju da su i sudovi bili otvoreni za novine i da su razumeli mnoge od preduslova koji su važni lizing društvima i danas.

4. Na osnovu navedenog, sledeća pitanja su identifikovana kao važna za pravilno funkcionisanje lizinga i kao preduslov za rast lizing društava, a samim tim i za rast ekonomije. Ujedno, ovi su bili najverovatnije i problemi sa kojima se Hipo Banka suočavala na Balkanu. 
5. Kao prvo, ima nedoumica oko toga koji oblici lizinga treba da budu regulisani posebnim zakonima. U nekim državama regiona samo je finansijski lizing podvrgnut takvom tretmanu (npr. Srbija), nasuprot tome lex specialis u drugim državama reguliše kako finansijski tako i operativni lizing (npr. Hrvatska). Uz to, ako ih uopšte ima, i zakonske definicije lizinga se često bitno razlikuju. Ponekad su definicije toliko komplikovane da stvaraju poteškoće u praksi.

6. Naročito je u tim pravnim sistemima problematično pitanje koja su tačno prava stranaka u lizing poslovima nakon docnje, u kojima lizing nije regulisan posebnim zakonom pa se analogno primenjuju pravila o kupoprodaji (kupoprodaja sa obročnim otplatama) ili o zakupu. Pitanje je i to koja su prava davaoca lizinga tada i da li se ona mogu kumulirati, odnosno kada i pod kojim uslovima. Ovaj set problema u SAD je poznat kao doktrina izbora pravnih lekova. I pored toga što je ova doktrina u SAD izgubila na važnosti, uticala je kako na sudove tako i na zakonodavce $u$ smislu da su znali ne samo da je jedno od krucijalnih pitanja kod ugovora o lizingu regulisanje baš prava stranaka nego i to da se to ne može rešiti arbitrerno nego uzimajući u obzir i bitne interese lizing društava.

7. Međutim, kako su već i rani vojvođanski slučajevi pokazali, jedan od najvećih problema davalaca lizinga je to da ni tada, a ni danas, nemaju pravnih mogućnosti da po docnji primaoca lizinga hitno povrate posed nad objektom lizinga. To se može učiniti samo uz pomoć suda, ali često samo nakon više godina parničenja, a za to vreme primalac lizinga ne samo da koristi predmet lizinga nego se stvar i delimično amortizuje. Primalac lizinga uz to može sakriti ili rastaviti i tako prodati predmet lizinga i time onemogućiti primaocu da ga povrati. U praksi SAD baš zato je prvobitno bilo da se predmet lizinga može čak i bez intervencije suda povratiti (self-help repossession) i ovo pravo davaoca lizinga (kao i založnih poverilaca) pravno je priznato. Evropski sistemi najčešće dozvoljavaju povraćaj samo uz pomoć sudova ili sudskih izvršilaca, postsocijalistički sistemi se isto tako ograđuju od anglosaksonskog pristupa bar na nivou prava i pravne politike. Nasuprot tome, u praksi davaoci lizinga često pribegavaju rešenjima koja su na rubu legitimnosti. Na primer, u slučaju lizinga putničkih automobila, zadrže jedan rezervni ključ, pa ako dođe do docnje, automobil jednostavno otključaju i odvezu u garažu davaoca lizinga u momentu kada se to može uraditi.

8. Kako je nerazvijenost lizinga mašina i opreme jedan od najvećih problema u regionu, članak se osvrće i na problem tzv. bezrezervno izvršujućih klauzula u kontekstu finansijskog lizinga (hell or high water clauses). Ove klauzule u praksi SAD su od presudnog značaja jer efikasno zaštićuju finansijere od prigovora vezanih za mane objekta lizinga. Kako 
sudovi bespogovorno priznaju ove klauzule kao sine qua non finansijskog lizinga, primaoci lizinga znaju da mane objekta lizinga niti ih oslobađaju od kontinuiranog plaćanja lizing rata, niti im omogućavaju olako blokiranje plaćanja kroz parničenje. Drugim rečima, nasuprot vojvođanskoj lizing kompaniji koja niti je mogla brzo da povrati objekte lizinga, niti se mogla odbraniti od rutinski započetih parnica koje su onemogućile kontinuiranu naplatu rata i preduzimanje izvršnih mera do okončanja parnice, u SAD i u razvijenim anglosaksonskim sistemima brzi povraćaj predmeta lizinga je ne samo moguć nego se poima kao suštinski preduslov lizing poslova.

9. Članak ujedno identifikuje faze dolaska lizinga u zemlje zapadnog Balkana i prikazuje pravo i socijalno-ekonomske prilike u njima koje su od uticaja na lizing.

Ključne reči: lizing (operativni, finansijski), lizing mašina, postrojenja i industrijske opreme, spasavanje banke, povraćaj poseda bez intervencije suda, pravna tehnika, finansiranje malih i srednjih preduzeća, pravna reforma.

Dostavljeno Uredništvu: 25. januara 2018. god.

Prihvaćeno za objavljivanje: 31. januara 2018. god. 